\title{
A southern North Sea Miocene dinoflagellate cyst zonation
}

\author{
D.K. Munsterman ${ }^{1, \star} \&$ H. Brinkhuis ${ }^{2}$
}

1 Netherlands Institute of Applied Geoscience TNO - National Geological Survey, P.O. Box 80015, 3508TA Utrecht, the Netherlands, Fax: +31 3025648 55, E-mail: dirk.munsterman@tno.nl (corresponding author)

2 Laboratory of Palaeobotany and Palynology, Utrecht University, Budapestlaan 4, 3584 CD Utrecht, the Netherlands

Manuscript received: April 2004; accepted: October 2004

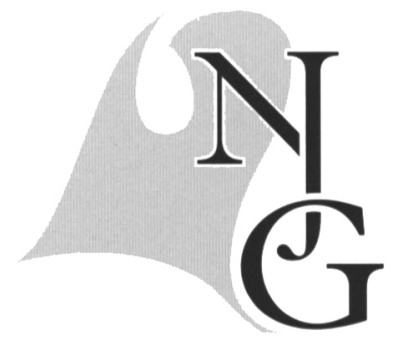

\begin{abstract}
An integrated stratigraphical analysis emphasizing organic-walled dinoflagellate cyst (dinocyst) distribution has been carried out on multiple boreholes penetrating the Miocene in the subsurface of the Netherlands (southern North Sea Basin). The bulk of the investigated successions is attributed to the Breda Formation, a regional lithostatigraphical unit most complete in the south-eastern part of the Netherlands. In concert with a first regional integrated bio (chrono) sequence-stratigraphical framework, fourteen informal dinocyst zones for the southern North Sea Miocene (SNSM), and three subzones are proposed for the Breda Formation. By also integrating (chrono)stratigraphic information from Mediterranean and North Atlantic dinocyst studies a first ever detailed age-model is here proposed for the Miocene in the subsurface of the Netherlands.
\end{abstract}

Keyzords: southern North Sea, the Netherlands, Miocene, Breda Formation, biostratigraphy, sequence stratigraphy, palynology, organic-walled dinoflagellate cysts

\section{Introduction}

Perhaps surprisingly, a comprehensive detailed stratigraphic synthesis of the marginal marine Late Oligocene (Chattian) and Neogene successions of the southern North Sea Basin is not yet established. Despite intense exploration in older deposits, Neogene (bio) chronostratigraphy is only available in very broad terms at best (e.g., Doppert et al., 1975; Van den Bosch, 1975; NAM and RGD, 1980; Letsch and Sissingh, 1983; Zagwijn, 1989; Van den Berg, 1996; Van Adrichem Boogaert and Kouwe, 1997; Verbeek et al., 2002). In the Netherlands, the bulk of the regionally thick Miocene succession is currently assigned to a single lithostratigraphical unit, the Breda Formation. This unit locally overlies the Veldhoven Formation of presumed Chattian to earliest Miocene age, or older deposits. Overlying strata have been assigned to the marine Oosterhout and fluviatile Kieseloölite formations, or to yet to be defined units (notably in the Dutch offshore sectors; NAM and RGD, 1980; Van Adrichem Boogaert and Kouwe, 1997). Detailed ageassessment of all of these Neogene deposits is still largely lacking and lateral relationships are unclear.

The few attempts of stratigraphic calcareous microplankton studies of the shallow marine Breda Formation have been frustrated by absence and/or poor preservation of index-taxa. Recent studies have however indicated that organic-walled dinoflagellate cysts (dinocysts) are abundant and diverse throughout most of the succession. Elsewhere application of Neogene dinocyst biostratigraphy has led to significant improvement in dating and paleoenvironmental understanding (e.g., Powell, 1986; Head et al., 1989; Brinkhuis et al., 1992; Zevenboom, 1995; De Verteuil and Norris, 1996; Head 1998, Dybkjaer and 
Rasmussen, 2000; Louwye, 2002), and there is every potential to achieve the same for the Breda Formation.

A study of multiple wells, spanning large parts of the Neogene in the subsurface of the Netherlands (Fig. 1) indeed indicates that a suite of dinocyst events consistently occurs in the Miocene of the southern North Sea Basin. Integrating quantitative palynological data with wire-line, lithological, and foraminifera and bolboforma studies, a first integrated bio (chrono) sequence-stratigraphical framework has recently been established (RGD, TNO-NITG, LPP internal reports; Munsterman, manuscript in preparation). Here we discuss the resulting dinocyst zonation for the Miocene.

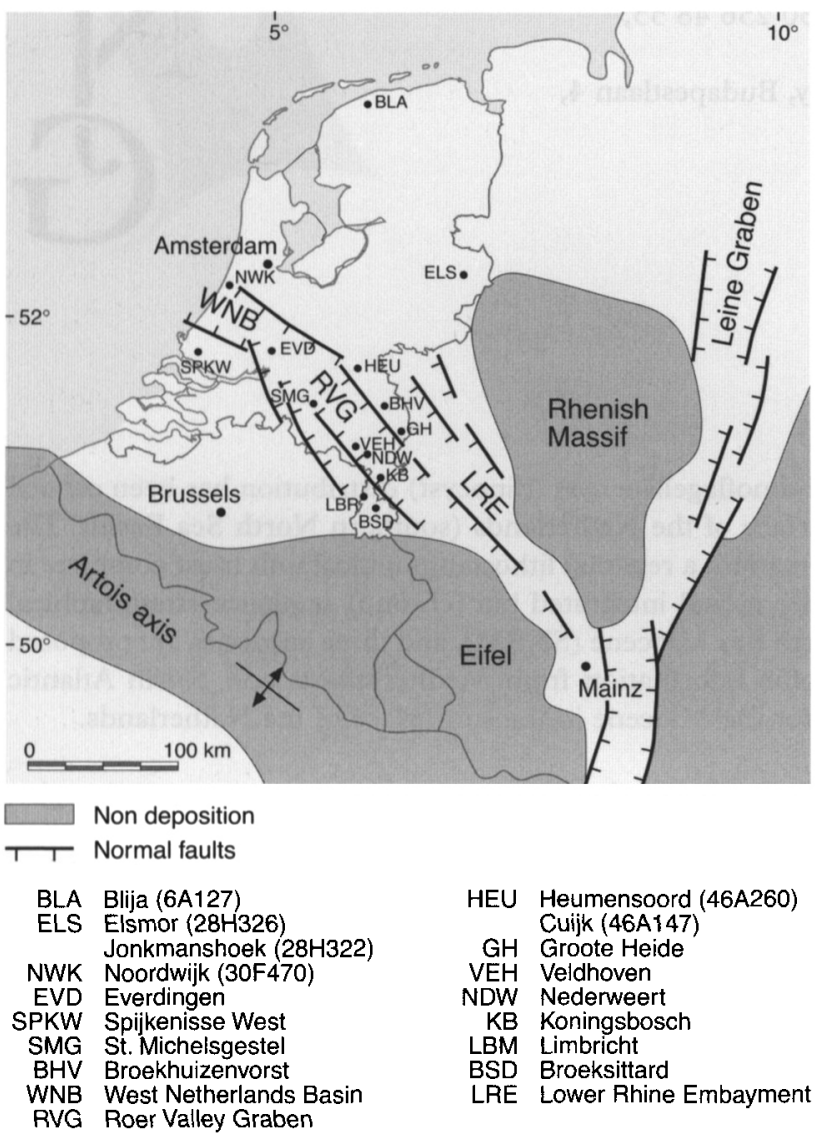

Fig. 1. Overview of the Rhine Graben system in northwest Europe (after Ziegler 1990).

\section{Geological and paleoenvironmental setting}

A complex Cenozoic rift system of approximately 1100 $\mathrm{km}$ long extends from the west coast of the Netherlands through West Germany and southeastern France into the western Mediterranean (Fig. 1). The Roer (Ruhr) Valley (or 'central Graben') rift system forms the main structural-physiographic unit of the socalled Lower Rhine Embayment, bordered by the Rhenish Massif in the east and by the Brabant Massif

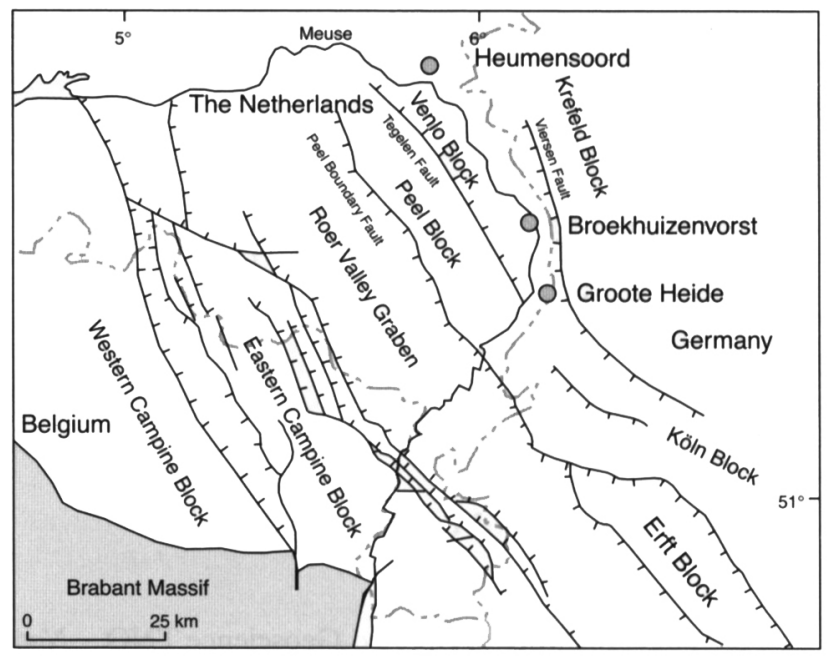

Fig. 2. Structural framework of the area (after map of Geluk et al., 1994).

in the southwest (Zagwijn, 1989; Geluk, 1990; Ziegler, 1990; 1994; Van den Berg, 1994, see Figs. 1 and 2).

The Roer Valley rift system is differentiated into several tectonic units, and is filled with up to $2000 \mathrm{~m}$ thick, largely Neogene shallow marine to continental deposits. To the northwest the graben broadens into the West Netherlands Basin (Fig. 1). Blocks of intermediate subsidence flank the Roer Valley Graben on both sides (Fig. 2). In the southwest these areas are the Eastern and Western Campine Blocks, while the Venlo, Peel and Köln Blocks are recognized in the northeast (Geluk et al., 1994). The deepest part of the Venlo-Peel Block is often referred to as the Venlo Graben (Van den Berg, 1994). The Peel Block has been uplifted $\sim 1000 \mathrm{~m}$ along the NW-SE oriented Peel Boundary Fault. The Tegelen Fault divides the Peel Block and the Venlo Block (Van Adrichem Boogaert and Kouwe, 1997). The Viersen Fault is the principal displacement zone that separates the Venlo Block and the northeastern Krefeld Block (see Fig. 2).

The Cenozoic successions of the Lower Rhine Embayment and southern part of the North Sea Basin were deposited in a paleoenvironmental setting ranging from coastal plain, deltaic to shallow marine (littoral and epineritic; Zagwijn, 1989). Up until the Rupelian there was minimal differential subsidence (Geluk, 1990). The entire area subsided uniformly, although intermittently, notably in the Eocene, inversion movements and erosion occurred. The uplift in the southeastern Netherlands was caused by the Pyrenean tectonic phase (Letsch and Sissingh, 1983). The earliest syn-rift deposits in the Rhine Graben have been dated as 'Late Eocene' (Geluk, 1990). The rift system started to develop in the Alpine foreland and propagated northwards (and southwards) to accommodate the stress from the Alpine-Mediterranean orogenic system. 
During the Rupelian the rifting progressively moved northward and the Rhine and Leine grabens developed a narrow seaway between the Alpine foredeep and the North Sea Basin (Vinken, 1988). In the Chattian the rifting became evident in the SE Netherlands (Geluk, 1994). It developed via an older fracture system, reactivating e.g., the Peel Boundary Fault. The rifting was accompanied by sinistral strikeslip faulting, moving the Roer Valley southwards relative to the Peel Horst. The faulting resulted in differential subsidence in the area of the Roer Valley and adjacent blocks. A strong eustatic sea level drop apparently occurred at the Rupelian-Chattian boundary (e.g., Hardenbol et al., 1998; Van Simaeys et al., in press). This fall led to substantial erosion of the top sets of the latest Rupelian highstand system tracts. The Veldhoven Formation, representing shallow marine Chattian deposits, is only present in a relatively small area, i.e. in the central and SE Netherlands (Letsch and Sissingh, 1983; Zagwijn, 1989). The Roer Valley Graben and the Lower Rhine Embayment developed as nearshore depocenters during the younger Oligocene. In northern, western and eastern Netherlands the marine Chattian is believed to be largely absent, mainly due to non-deposition (synsedimentary erosion) and/or to later erosion (Zagwijn, 1989).

During the Neogene, marginal marine successions (all assigned to the Breda Formation) again covered most of the Netherlands, with the exception of the outermost southwestern, southeastern and eastern parts. After the Burdigalian rise in sea level, the area of marine sedimentation increased compared to the Chattian. During the Early Miocene, the Leine Graben and part of the Roer Valley Graben were affected by inversion, possibly related to the onset of the thermal uplift of the Rhenish Massif, which included volcanic activity in the Siebengebirge (Teichmüller, 1972; Sissingh, 2003). Volcanic activity peaked during the Early Miocene (Lippolt, 1983), while also increase in differential movements (Savian tectonic phase) during this time have been proposed for the Roer Valley Graben and the Peel Block areas, although subsidence rates in the graben apparently did not accelerate before the Pliocene (Zijerveld et al., 1992).

The relatively slow subsidence in combination with overall warm and humid climates led to considerable peat accumulation during the late Early to early Late Miocene in parts of the Roer Valley Graben area (e.g., Utescher et al., 2000). During the Late Miocene, besides the Roer Valley Graben, a second depocenter developed, i.e. the Zuiderzee Basin. Sediments supplied by the fluvial systems from the uplifting (Alpine) hinterland were trapped in the two marine depocenters. Therefore these sequences may be absent or very condensed more distally (Zagwijn, 1989). The position of the coastline varied from extending beyond the present German border to a more western position into the southeastern Netherlands, shifting over more than $100 \mathrm{~km}$, also influenced by the strong Miocene eustatic sea level fluctuations.

The northwestern progradation of the paleo-Rhine (and Meuse; Van den Berg, 1996) delta continued in the southeastern part of the Netherlands during the Late Miocene and Pliocene, leading to the deposition of the fluvial Kieseloölite Formation (See: http:// www.nitg.tno.nl/nomenclator/Shallow/nl/fluviatiel/ $\mathrm{kiezel} / \mathrm{map} / \mathrm{html}$ ). These deposits laterally interfinger with the marine successions of the Oosterhout and younger Maassluis formations (See: e.g. http://www. nitg.tno.nl/nomenclatorShallow/nl/marien/oosterhout/ map.html). The main sediment accumulation shifted from the Zuiderzee area towards the main axis of the North Sea Basin. Although shallowing and shifting to the northwest, a prodelta depocenter was maintained in the Roer Valley Graben during the Pliocene (Fig. 1).

As stated above, the Breda Formation is represented virtually everywhere in the subsurface of the Netherlands. According to its current definition (NAM and RGD, 1980; Van Adrichem Boogaert and Kouwe, 1997) the formation consists of glauconitic sands, sandy clays and clays. In many places a glauconiticrich layer occurs at the base, which has become the criterion for recognition of the base of the formation. In this respect the original definition of the Breda Formation, which initially also included strata from below this glauconitic-rich layer (Doppert et al., 1975), has been slightly amended. The thickness of the Breda Formation varies strongly from less than 1 to more than $700 \mathrm{~m}$ (TNO-NITG internal reports). The upper limit of the Breda Formation is currently taken at the uppermost occurrence of greensands or clays rich in glauconite. It is overlain by the fluviatile, coarse grained deposits of the Kieseloölite Formation in the southeastern part of the Netherlands (Fig. 3). Elsewhere the upper boundary has been placed at the transition to the marine Oosterhout Formation, which is less glauconitic, grey-coloured and sometimes rich in shells (crags).

In the central and southeastern Netherlands the formation rests on the Upper Oligocene-Lower Miocene Veldhoven Formation. The lower boundary of the Breda Formation coincides with the transition from the Middle to the Upper North Sea Group. Elsewhere the Breda Formation unconformably rests on the Rupel Formation (Lower Oligocene) or, locally, on even older deposits. The lower boundary of the Breda Formation is difficult to establish in part of the 


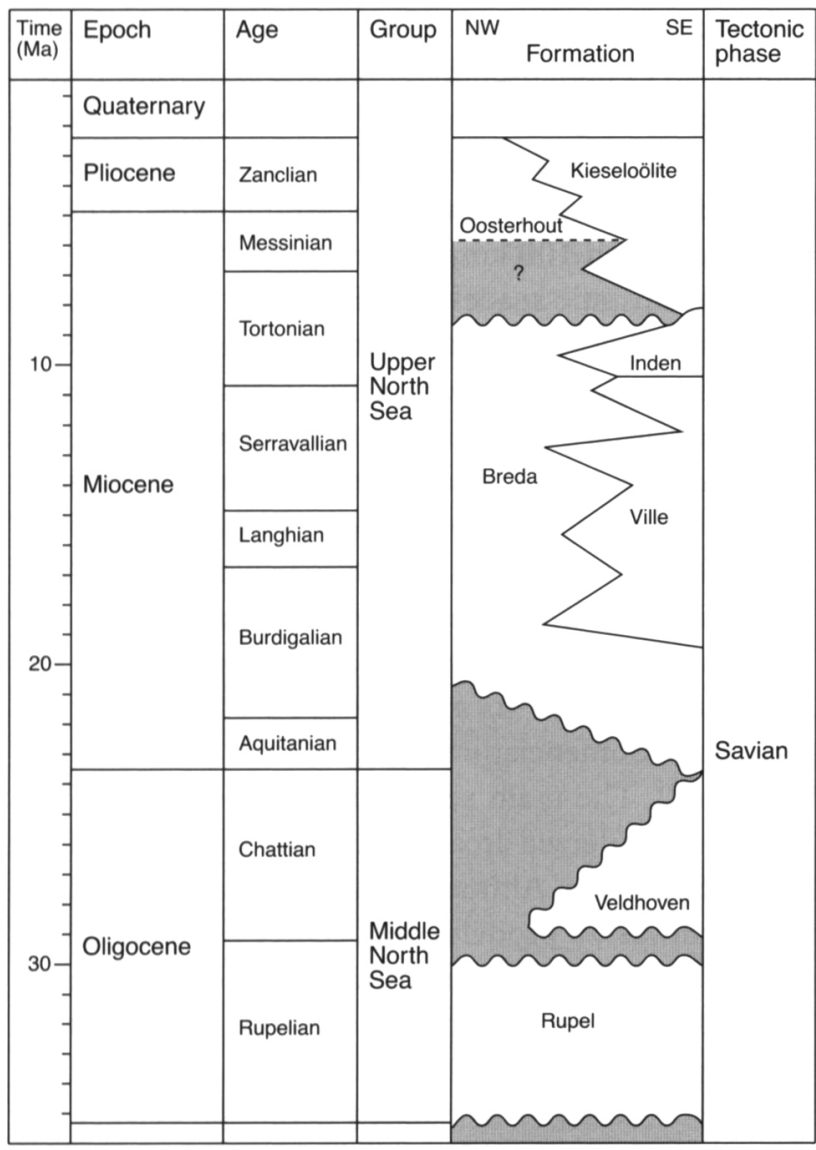

Fig. 3. Litho-chronostratigraphic chart for the southern Netherlands and adjacent area in Germany.

Roer Valley Graben and on the Peel/Venlo Blocks, since the transition from the glauconitic beds of the Veldhoven Formation into the greensands of the Breda Formation is gradual. Typically, therefore, in the Breda-type borehole Groote Heide from 1992, the Veldhoven Formation was not recognized. The Breda Formation, then recognized between 99.75$632 \mathrm{~m}$ at Groote Heide, was considered to overlie the Rupel Formation. Borehole Groote Heide was proposed as the lectostratotype section for the Breda Formation by the TNO-NITG (internal report 1998), and replaces its type, borehole Rijsbergen (50A0154), interval 174-234 m below surface, which is only $60 \mathrm{~m}$ along hole and incomplete. The Breda Formation at the southern Venlo Block is extensive and complete (TNO-NITG internal reports).

\section{Material and methods}

One hundred and ten airlift samples from well Groote Heide, interval 85-689 m were selected and analysed (see distribution chart on NJG webpage). The same set of samples was examined for foraminifera and bolboforma (TNO-NITG internal reports). The transition from glauconitic clays to glauconitic sands (and silts) at $496.70 \mathrm{~m}$ depth is considered to represent the base of the Breda Formation. The top of the formation is recognized at $99.75 \mathrm{~m}$ depth, on the basis of the transition to coarse-grained sands which are associated with the Kieseloölite Formation.

Other wells (Fig. 1) on the Venlo Block have been included in the macro- and microfossil studies to offer a framework for identification of patterns between the succession of dinocyst events and for the recognition of trends in lithofacies and sequence stratigraphy. All samples have been palynologically processed at the Laboratory of Palaeobotany and Palynology at the University of Utrecht using standard techniques, involving $\mathrm{HCl}$ and $\mathrm{HF}$ digestion, no oxidation, $15 \mu \mathrm{m}$ sieving, and preparation of at least two residue slides. Dinocyst taxonomy is according to that cited in Williams et al. (1998).

This paper is principally concerned with the recognition of stratigraphically consistent Miocene dinocyst events and chronostratigraphic assessment. The chronostratigraphic evaluation of the dinocyst events is based on the available Late Oligocene-Miocene palynological contributions in NW Europe (e.g., Gerlach, 1961; Morgenroth, 1966; Benedek, 1972; Piasecki, 1980; Sarjeant, 1984; Powell, 1986; Herngreen, 1987; Biffi and Manum, 1988; Londeix and Jan du Chene, 1988; Manum et al., 1989; Mudie, 1989; Brinkhuis et al., 1992; Powell, 1992; Strauss and Lund, 1992; Lentin, 1993; Lund et al., 1993; Stover and Hardenbol, 1993; Versteeg and Zevenboom, 1995; Zevenboom, 1995; De Verteuil and Norris, 1996; Stover et al., 1996; Louwye and Laga, 1998; Williams et al., 1998; Williams and Manum, 1999; Dybkjaer and Rasmussen, 2000; Louwye, 1999; 2000; Lund and Heilmann-Clausen, 2001; Van Simaeys et al., in press), and also considers the recent global compilation by Williams et al. (2004). The latter study makes use of paleomagnetic and/or calcareous plankton biostratigraphic calibration of dinocyst events, mainly derived from Mediterranean and Southern Ocean studies, based on the numerical timescale of Berggren et al. (1995). Resulting age-assessments for the southern North Sea Basin, further discussed below, have been cross-validated by correlation to recognized sealevel fluctuations using the sequence and a chronostratigraphic chart for NW Europe of Hardenbol et al. (1998). Recognition of the Dutch third-order Neogene sequences is based on changes in e.g., sporomorph/dinocyst ratios, the percentages of bisaccates (to the total sum sporomorphs), relative proportion of eco-dinocyst groups (e.g., sensu Brinkhuis, 1994), foraminifera associations and the $\gamma$-ray $\log$ expressions (Munsterman, manuscript in preparation). 


\section{Results}

The composition of the dinocyst assemblages is highly variable (Figs. 4-21) although typically, several intervals are characterized by a dominance of a single taxon (e.g., Homotryblium floripes-plectilum group), due to restricted marine conditions. In general, however, representatives of Dapsilidinium, Hystrichokolpoma, Lingulodinium, Operculodinium, Spiniferites and Systematophora are common in most samples. The sporomorph content is dominated by bisaccates. Overall preservation is good, although the relatively low percentages of protoperidinioid species may be taken to indicate mild (insitu) oxidation (cf. Reichart and Brinkhuis, 2003).

Roughly fifty Late Oligocene-Miocene dinocyst events are consistently recognized between investigated boreholes (Fig. 1), while up to 17 third-order eustatic sea level sequences have been recognized on the basis of our integrated studies so far. Informal (interval) dinocyst zones for the Late Oligocene ( 3 zones) are presented elsewhere (Van Simaeys et al., submitted.) The fourteen Miocene zones are described below (Fig. 22). The zones are typically defined by the highest (HO) and lowest occurrence (LO) of taxa.

\section{SNSM1 (southern North Sea Miocene 1) zone}

\section{Definition}

The interval from the $\mathrm{HO}$ of Distatodinium biffii to the $\mathrm{HO}$ of Chiropteridium spp. (Fig. 4).

\section{Characteristics}

Several typical Paleogene taxa have their $\mathrm{HO}$ in this zone that spans the Oligocene/Miocene boundary, viz: Deflandrea phosphoritica, Glaphyrocysta spp., Hystrichokolpoma cinctum, Hystrichokolpoma sp. cf. H. oceanicum of Wilpshaar et al. (1996), and Membranophoridium aspinatum. Membranilarnacia? picena (Fig. 5) becomes more consistent throughout, while Ectosphaeropsis burdigalensis (Fig. 9) has its LO within this zone. Taxa that are more common include Cordosphaeridium cantharellum, Polysphaeridium zoharyi, Spiniferites spp., Systematophora placacantha and Thalassiphora pelagica. Paralecaniella indentata relative numbers increase while the Homotryblium floripes/plectilum group may be abundant.

\section{Lithostratigraphy}

Middle North Sea Group; Veldhoven Formation (Van Adrichem Boogaert and Kouwe, 1997).

\section{Age}

Latest Chattian-early Aquitanian.
Reference section

Heumensoord (46A0260), interval 358-395 m.

Additional reference sections

Broekhuizenvorst (52E0114), interval 261-276 m; Groote Heide (58F0064), interval 440.2-485.7 m.

Remarks

This zone is more or less equivalent to the Chiropteridium galea Interval Zone (DN1) of De Verteuil and Norris (1996). Powell (1986) recorded the $\mathrm{HO}$ of Chiropteridium galea from the lower NN2 Zone at the Lemme section, Northwest Italy ( 22.2 Ma; Berggren et al., 1995).

This zone is subdivided into three subzones SNSM1a, SNSM1b and SNSM1c.

\section{SNSM1a (southern North Sea Miocene 1a) subzone}

\section{Definition}

The interval from the HO of Distatodinium biffii to the HO of Glaphyrocysta spp.

\section{Characteristics}

The HO of Deflandrea phosphoritica and the highest consistent occurrence (HCO) of Hystrichokolpoma cinctum are recorded in this zone. Ectosphaeropsis burdigalensis has it's LO within this subzone. Homotryblium floripes/plectilum may appear in abundant numbers (up to $40 \%$ ). Paralecaniella indentata is common. Other dinocysts recorded in higher abundances are Operculodinium spp., Polysphaeridium zoharyi, Spiniferites spp., and Systematophora placacantha.

Age

Latest Chattian - earliest Aquitanian.

Reference section

Heumensoord (46A0260), interval 368-395 m.

\section{SNSM1b (southern North Sea Miocene 1b) subzone}

\section{Definition}

The interval from the $\mathrm{HO}$ of Glaphyrocysta spp. to the lowest consistent occurrence (LCO) of Membranilarnacia? picena (Fig. 5).

\section{Characteristics}

Homotryblium floripes/plectilum and Paralecaniella are common. Operculodinium piaseckii has its LO in this subzone. 
Age

Early Aquitanian.

Reference section

Broekhuizenvorst (52E0114), interval 261-276 m.

\section{SNSM1c (southern North Sea Miocene 1c) subzone}

Definition

The interval from the LCO of Membranilarnacia? picena to the $\mathrm{HO}$ of Chiropteridium spp.

\section{Characteristics}

Hystrichokolpoma cinctum, Hystrichokolpoma sp. cf. $H$. oceanicum and Membranophoridium aspinatum have their $\mathrm{HO}$ in this subzone. Homotryblium floripes/ plectilum achieves high relative abundances (up to $55 \%)$.

Age

Early Aquitanian

Reference section

Groote Heide (58F0064), interval 440.2-462.75 m. Additional reference section: Heumensoord (46A0260), interval 358-367 m.

\section{SNSM2 (southern North Sea Miocene 2) zone}

\section{Definition}

The interval from the $\mathrm{HO}$ of Distatodinium biffii to the HO of Membranilarnacia? picena (Fig. 5).

\section{Characteristics}

The interval is marked by the $\mathrm{HO}$ of Homotryblium vallum and the LOs of Cousteaudinium aubryae (Fig. 8) and Hystrichosphaeropsis obscura (Fig. 14). Taxa that are quantitatively well-represented include Apteodinium spp., Dapsilidinium spp., Distatodinium paradoxum (Fig. 12), Homotryblium floripes/plectilum, Lingulodinium machaerophorum, Polysphaeridium zoharyi, Spiniferites spp., Systematophora placacantha and Reticulatosphaera actinocoronata.

\section{Lithostratigraphy}

Middle North Sea Group; Veldhoven Formation (Van Adrichem Boogaert and Kouwe, 1997).

Age

Late Aquitanian - (earliest) early Burdigalian.

Reference section

Groote Heide (58F0064), interval 403.7-437.2 m.
Remarks

The HO of Membranilarnacia? picena is reported from the Nematosphaeropsis downiei Interval Zone at the Contessa section, northern Italy (Zevenboom, 1995). Its chronostratigraphic position is there calibrated magnetostratigraphically against $\mathrm{C} 6 \mathrm{~N}(\sim 19.6 \mathrm{Ma}$; Berggren et al., 1995).

\section{SNSM3 (southern North Sea Miocene 3) zone}

\section{Definition}

The interval from the $\mathrm{HO}$ of Membranilarnacia? picena (Fig. 5) to the $\mathrm{HO}$ of Cordosphaeridium cantharellum (Fig. 6).

\section{Characteristics}

Caligodinium pychnum and Leptodinium italicum have their HOs in this zone. Common are Batiacasphaera spp., Dapsilidinium spp., Lingulodinium machaerophorum, Operculodinium spp., Reticulatosphaera actinocoronata and Spiniferites spp.

\section{Lithostratigraphy}

Middle North Sea Group; Veldhoven Formation (Van Adrichem Boogaert and Kouwe, 1997).

Age

Early-middle Burdigalian.

Reference section

Groote Heide (58F0064), interval 317.8-400.7 m.

Remarks

Zevenboom (1995) recorded the $\mathrm{HO}$ of Cordosphaeridium cantharellum in his Selenopemphix brevispinosa Interval Subzone of the Hystrichokolpoma reductum Interval Zone in the Cortemilia section, northern Italy. The event is there calibrated against the top of Chron C5Dr ( 17.6 Ma; Berggren et al., 1995).

\section{SNSM4 (southern North Sea Miocene 4) zone}

\section{Definition}

The interval from the $\mathrm{HO}$ of Cordosphaeridium cantharellum to LO of Labyrinthodinium truncatum (Fig. 16).

\section{Characteristics}

Sumatradinium soucouyantiae appears in this zone, while the LOs of Barssidinium graminosum and $B$. wrennii are noted as well. The associations are dominated by Apteodinium spiridoides, Batiacasphaera spp., Operculodinium centrocarpum, Spiniferites spp. and Systematophora placacantha. Paralecaniella and 
Pediastrum may reach common to abundant values in the associations.

\section{Lithostratigraphy}

Upper North Sea Group; Breda Formation (Van Adrichem Boogaert and Kouwe 1997).

Age

Late Burdigalian or early Langhian (see Discussion).

Reference section

Groote Heide (58F0064), interval 296.5-314.8 m.

Remarks

This zone comprises the DN3 Zone of De Verteuil and Norris (1996). Sumatradinium soucouyantiae apparently has a younger LO in the North Sea Basin compared to the records from the U.S. Atlantic margin (DN 2 zone, De Verteuil and Norris, 1996). This may be due to climatic differences since Sumatradinium spp. are typical tropical taxa.

\section{SNSM5 (southern North Sea Miocene 5) zone}

\section{Definition}

The interval from the LO of Labyrinthodinium truncatum (Fig. 16) to the LO of Unipontidinium aquaeductum (Fig. 11).

\section{Characteristics}

Cerebrocysta poulsenii, 'Imperfectodinium bulbosum' (Zevenboom, 1995, ms) and 'Palaeocystodinium ventricosum' (Fig. 15) (Zevenboom, 1995, ms) have their LO in this zone. Lingulodinium machaerophorum, Operculodinium centrocarpum, Reticulatosphaera actinocoronata, Systematophora placacantha (Fig. 7) and Spiniferites spp. are common in this zone. The colonial freshwater alga Pediastrum is abundant, while the acritarch Paralecaniella may be common.

\section{Lithostratigraphy}

Upper North Sea Group; Breda Formation (Van Adrichem Boogaert and Kouwe, 1997).

Age

Langhian.

Reference section

Groote Heide (58F0064), interval 275.3-291.6 m.

\section{Remarks}

The zone is identical to the Labyrinthodinium truncatum Interval Zone of Zevenboom (1995). The LO of Labyrinthodinium truncatum at the Cessole section, northern Italy, is calibrated against in the basal part of subchron C5Bn2n ( 15.2 Ma; Zevenboom, 1995). De Verteuil and Norris (1996) proposed that the LO of Labyrinthodinium truncatum approximates the Burdigalian-Langhian transition $(\sim 16.4 \mathrm{Ma})$. In their discussion, De Verteuil and Norris (1996) refer to possible calibration against the planktonic foraminifera upper N8 or N9 Zone and calcareous nannofossil NN5 Zone. Our integrated biochrono-sequence stratigraphy places the event at 15,8 $\mathrm{Ma}$ in the southern North Sea Basin.

\section{SNSM6 (southern North Sea Miocene 6) zone}

\section{Definition}

The interval from the LO of Unipontidinium aquaeductum (Fig. 11) to the $\mathrm{HO}$ of Cousteaudinium aubryae (Fig. 8).

\section{Characteristics}

The lowest appearances of Gramocysta verricula (Fig. 20) are recorded at the top of this zone. The assemblage is dominated by Batiacasphaera hirsuta, Lingulodinium machaerophorum, Operculodinium centrocarpum, Polysphaeridium zoharyi, Reticulatosphaera actinocoronata, Spiniferites spp. and Systematophora placacantha (Fig. 7).

\section{Lithostratigraphy}

Upper North Sea Group; Breda Formation (Van Adrichem Boogaert and Kouwe, 1997).

Age

Latest Langhian.

Reference section

Broekhuizenvorst (52E0114), interval 178-197 m.

Additional reference section

Heumensoord (46A0260), interval 284-306 m.

\section{Remarks}

The LO of Unipontidinium aquaeductum is calibrated against the upper part of $\mathrm{C} 5 \mathrm{Bn} 2 \mathrm{n}(\sim 15.1 \mathrm{Ma})$ in Italy (Zevenboom, 1995), while the $\mathrm{HO}$ of Cousteaudinium aubryae is calibrated against the base of $\mathrm{C} 5 \mathrm{Bn} 1 \mathrm{n}$ $(\sim 14.9 \mathrm{Ma})$.

\section{SNSM7 (southern North Sea Miocene 7) zone}

\section{Definition}

The interval from the $\mathrm{HO}$ of Cousteaudinium aubryae (Fig. 8) to the HO of 'Palaeocystodinium ventricosum' Zevenboom (1995, ms) (Fig. 15). 


\section{Characteristics}

An index-event for this zone is the LO of 'Headinium miocenicum' Zevenboom, 1995, ms., while Apteodinium spiridoides has its $\mathrm{HO}$ in this zone. Batiacasphaera, Labyrinthodinium, Lingulodinium, Operculodinium, Systematophora and Spiniferites spp. are common in this zone. Paralecaniella spp. are common as well.

Lithostratigraphy

Upper North Sea Group; Breda Formation (Van Adrichem Boogaert and Kouwe, 1997).

Age

Early-middle Serravallian.

Reference section

Groote Heide (58F0064), interval 217.8-251.9 m.

Additional reference section

Broekhuizenvorst (52E0114), interval 133-173 m.

\section{Remarks}

The HO of 'Palaeocystodinium ventricosum' is reported by Zevenboom (1995) from the middle part of his Operculodinium eirikianum Interval Subzone of the Hystrichosphaeropsis pontiana Interval Zone, at the Cassinasco section, northern Italy. There, this event is calibrated against the base of Chron C5Ar $(\sim 13 \mathrm{Ma})$.

\section{SNSM8 (southern North Sea Miocene 8) zone}

\section{Definition}

The interval from the $\mathrm{HO}$ of 'Palaeocystodinium ventricosum' (Fig. 15) Zevenboom (1995, ms) to the HO of Unipontidinium aquaeductum (Fig. 11).

\section{Characteristics}

Batiacasphaera sphaerica, Dapsilidinium spp., Habibacysta tectata, Labyrinthodinium truncatum, Lingulodinium machaerophorum, Palaeocystodinium golzowense, Polysphaeridium zoharyi, Reticulatosphaera actinocoronata, Spiniferites spp. and Systematophora placacantha (Fig. 7) comprise the majority of the dinocysts in the associations of this zone.

\section{Lithostratigraphy}

Upper North Sea Group; Breda Formation (Van Adrichem Boogaert and Kouwe, 1997).

Age

Middle Serravallian

Reference section

Heumensoord (46A0260), interval 250-256 m.
Additional reference section

Groote Heide (58F0064), interval 199.3-202.3 m.

Remarks

Zevenboom (1995) correlated the HO of Unipontidinium aquaeductum to base C5An $(\sim 12.4 \mathrm{Ma})$.

\section{SNSM9 (southern North Sea Miocene 9) zone}

\section{Definition}

The interval from the $\mathrm{HO}$ of Unipontidinium aquaeductum (Fig. 11) to the LO of Achomosphaera andalousiensis (Fig. 17).

\section{Characteristics}

Batiacasphaera hirsuta, Habibacysta tectata, Hystrichokolpoma rigaudiae, Lingulodinium machaerophorum, Operculodinium centrocarpum, Reticulatosphaera actinocoronata, Spiniferites ramosus and Systematophora placacantha are common in this zone, as is Paralecaniella indentata.

\section{Lithostratigraphy}

Upper North Sea Group; Breda Formation (Van Adrichem Boogaert and Kouwe, 1997).

Age

Middle-late Serravallian.

Reference section

Heumensoord (46A0260), interval 220-241 m.

SNSM10 (southern North Sea Miocene 10) zone

Definition

The interval from the LO of Achomosphaera andalousiensis (Fig. 17) to the $\mathrm{HO}$ of Cerebrocysta poulsenii (Fig. 18).

\section{Characteristics}

Spiniferites spp. dominate the associations of this zone. Common are Habibacysta tectata, Hystrichokolpoma rigaudiae and Operculodinium centrocarpum.

\section{Lithostratigraphy}

Upper North Sea Group; Breda Formation (Van Adrichem Boogaert and Kouwe, 1997).

Age

Middle-late Serravallian.

Reference section

Groote Heide (58F0064), interval 193.90-196.30 m. 
Remarks

This zone is the equivalent of the Achomosphaera andalousiensis (Aan) Interval Zone of Zevenboom (1995). In Italy, the LO of Achomosphaera andalousiensis is calibrated magnetostratigraphically with the upper part of the subchron C5An ( 12.2 Ma) by Zevenboom (1995). The HO of Cerebrocysta poulsenii is calibrated against basal $\mathrm{C} 5 \mathrm{r}(\sim 11.7 \mathrm{Ma})$ in Italy (Zevenboom, 1995).

SNSM11 (southern North Sea Miocene 11) zone

Definition

The interval from the $\mathrm{HO}$ of Cerebrocysta poulsenii (Fig. 18) to the $\mathrm{HO}$ of Cannosphaeropsis passio (Fig. 19).

\section{Characteristics}

Cannosphaeropsis passio first appears in this zone. Paralecaniella may dominate the associations. Habibacysta tectata, Lingulodinium, Operculodinium and Spiniferites spp. are common.

\section{Lithostratigraphy}

Upper North Sea Group; Breda Formation (Van Adrichem Boogaert and Kouwe, 1997).

Age

Late(st) Serravallian - earliest Tortonian.

Reference section

Groote Heide (58F0064), interval 144.8-193.55 m.

Additional reference section

Heumensoord (46A0260), interval 160-211 m.

\section{Remarks}

This zone comprises the Cannosphaeropsis passio Zone (DN 7) De Verteuil and Norris (1996). Zevenboom (1995) reported the HO of Cannosphaeropsis passio from the top of subchron $\mathrm{C} 5 \mathrm{Cr}(\sim 11 \mathrm{Ma})$ on the basis of the Italian sections.

\section{SNSM12 (southern North Sea Miocene 12) zone}

\section{Definition}

The interval from the $\mathrm{HO}$ of Cannosphaeropsis passio (Fig. 19) to the HO of Palaeocystodinium golzowense.

\section{Characteristics}

Locally Gramocysta verricula, Labyrinthodinium truncatum and Selenopemphix brevispinosum are common values. In general, Habibacysta tectata, Hystrichokolpoma rigaudiae, Lingulodinium machaerophorum,
Operculodinium spp., Reticulatosphaera actinocoronata, and Spiniferites spp. are abundant in this zone.

\section{Lithostratigraphy}

Upper North Sea Group; Breda Formation (Van Adrichem Boogaert and Kouwe, 1997).

Age

Early-middle Tortonian.

Reference section

Groote Heide (58F0064), interval 124.8-141.8 m.

Additional reference section

Heumensoord (46A0260), interval 140-156 m.

\section{Remarks}

The HO of Palaeocystodinium golzowense is calibrated against subchron C4An $(\sim 8.7 \mathrm{Ma})$ in Italy (Zevenboom, 1995). This matches the findings of De Verteuil and Norris (1996).

\section{SNSM13 (southern North Sea Miocene 13) zone}

\section{Definition}

The interval from the $\mathrm{HO}$ of Palaeocystodinium golzowense to the $\mathrm{HO}$ of Systematophora placacantha (Fig. 7).

\section{Characteristics}

Selenopemphix armageddonensis (Fig. 21) first appears in this zone. Common are Batiacasphaera spp., Habibacysta tectata, 'Headinium miocenicum', Lingulodinium machaerophorum, Operculodinium centrocarpum, Reticulatosphaera actinocoronata, Selenopemphix (including $S$. brevispinosum and $S$. dionaeacysta) and Spiniferites spp.

\section{Lithostratigraphy}

Upper North Sea Group; Breda Formation (Van Adrichem Boogaert and Kouwe, 1997).

Age

Middle Tortonian.

\section{Reference section}

Groote Heide (58F0064), interval 106.8-120.8 m.

Additional reference section

Heumensoord (46A0260), interval 125-134 m.

Remarks

Zevenboom (1995) calibrated the HO of Systematophora placacantha against the $\mathrm{C} 4 \mathrm{r} / \mathrm{C} 4 \mathrm{n}$ transition $(\sim 8.1 \mathrm{Ma})$ in Italy. 


\section{SNSM14 (southern North Sea Miocene 14) zone}

\section{Definition}

The interval from the $\mathrm{HO}$ of Systematophora placacantha (Fig. 7) to the $\mathrm{HO}$ of Labyrinthodinium truncatum.

\section{Characteristics}

Gramocysta verricula (Fig. 20) has its $\mathrm{HO}$ within this zone. Dinocysts with a Miocene or even earlier origin like Cordosphaeridium minimum, Hystrichosphaeropsis obscura, Melitasphaeridium choanophorum and Reticulatosphaera actinocoronata are still present. These taxa continue to occur above the $\mathrm{HO}$ of Labyrinthodinium truncatum.

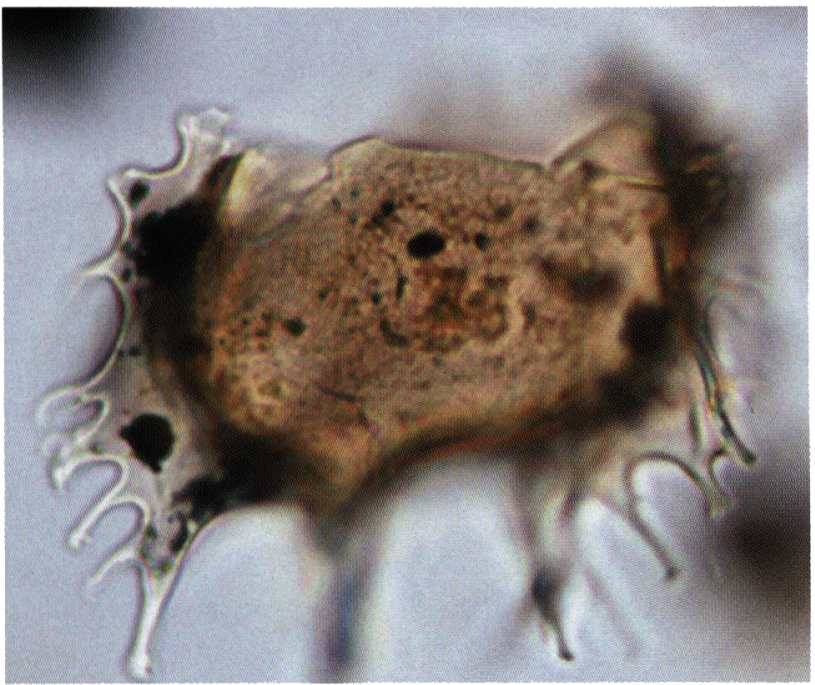

Fig. 4. Chiropteridium galea. GH $635.5-637.7 \mathrm{~m}$. Central body $62 \times 84 \mu \mathrm{m}$.

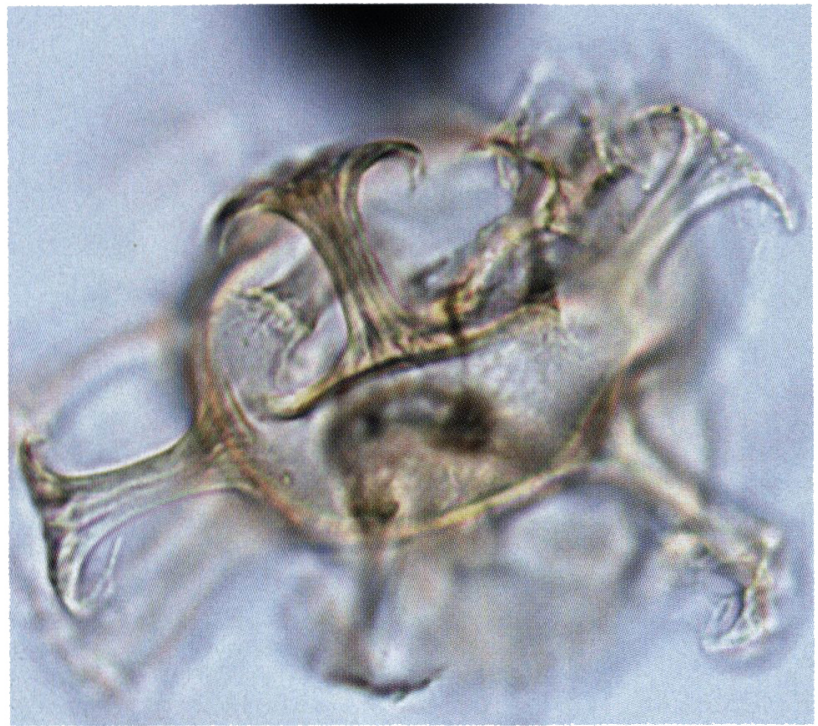

Fig. 6. Tityrosphaeridium cantharellus. GH 403.7-406.7 m. Central body $45 \times 62 \mu \mathrm{m}$; processus $25 \mu \mathrm{m}$.

\section{Lithostratigraphy}

Upper North Sea Group; Breda Formation (Van Adrichem Boogaert and Kouwe, 1997).

Age

Late Tortonian.

Reference section

Heumensoord (46A0260), interval 109-121 m.

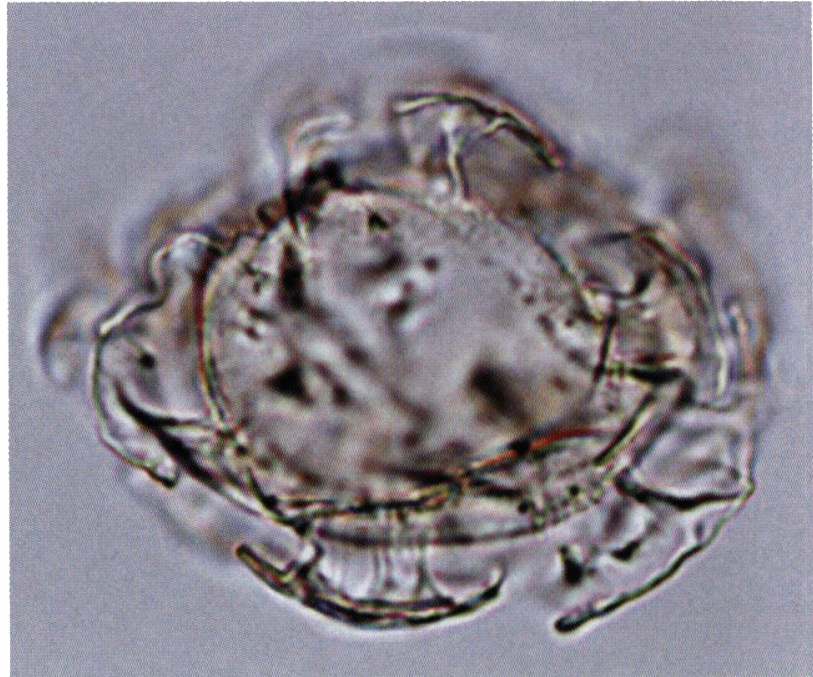

Fig. 5. Membranilarnacia? picena. GH 421.7-424.7 $\mathrm{m}$. Overall dimensions $51 \times 63 \mu \mathrm{m}$.

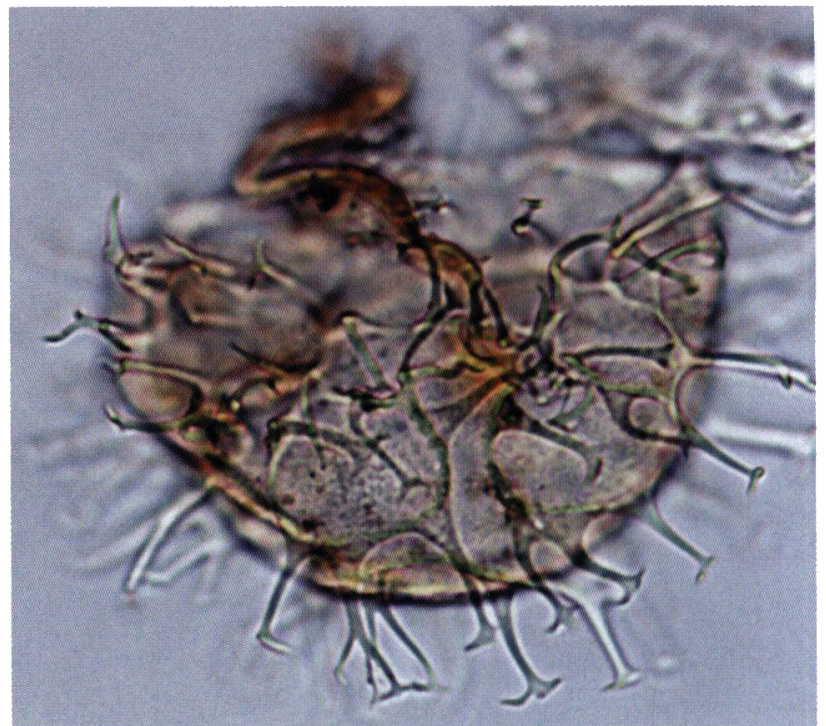

Fig. 7. Systematophora placacantha. GH $379.7-382.7 \mathrm{~m}$. Central body diameter $78 \mu \mathrm{m}$. 


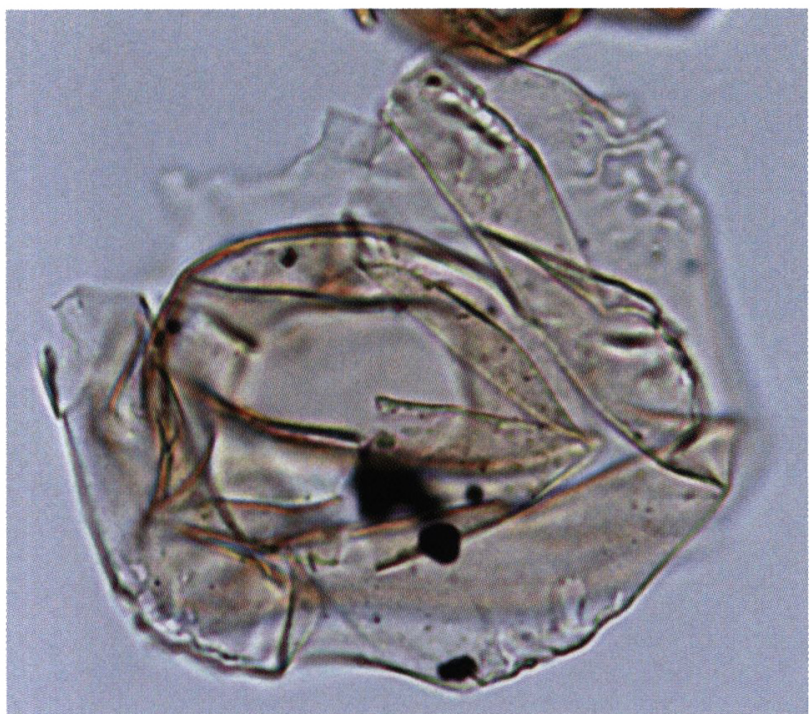

Fig. 8. Cousteaudinium aubryae. GH 434.2-437.2 m. Diameter periblast $85 \mu \mathrm{m}$.

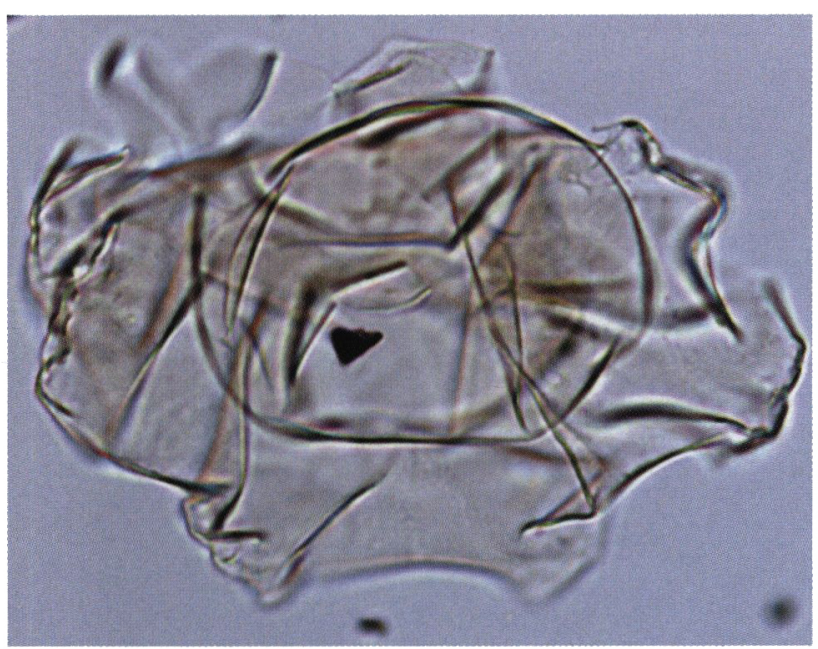

Fig. 10. Cousteaudinium aubryae. GH 311.8-314.8 m. Dimensions periblast $69 \times 103 \mu \mathrm{m}$.

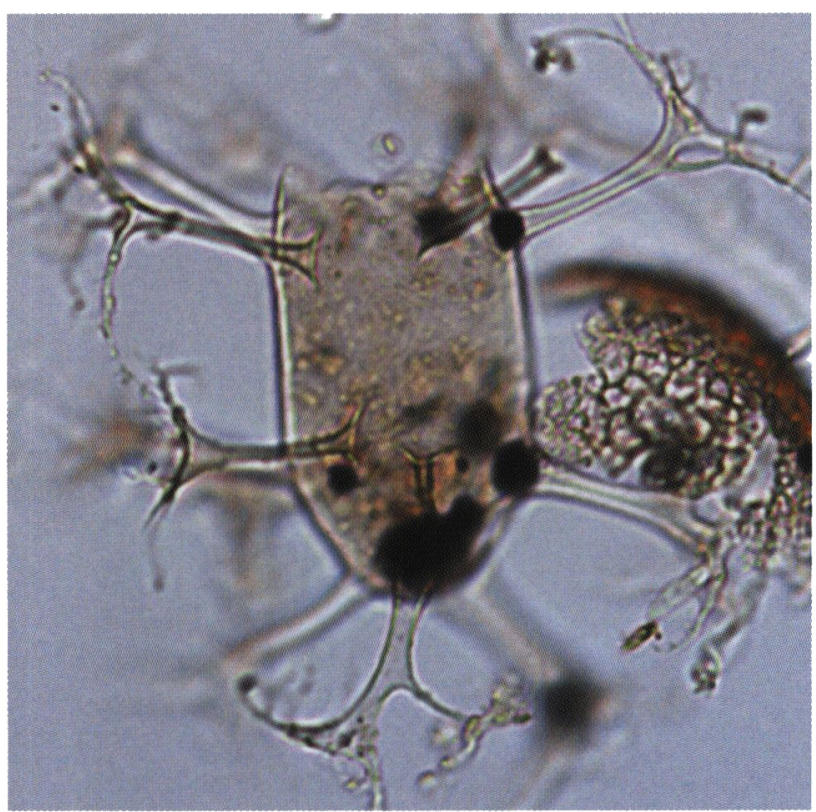

Fig. 12. Distatidonium paradoxum. GH 415.7-418.7 m. Central body $51 \times 29 \mu \mathrm{m}$.

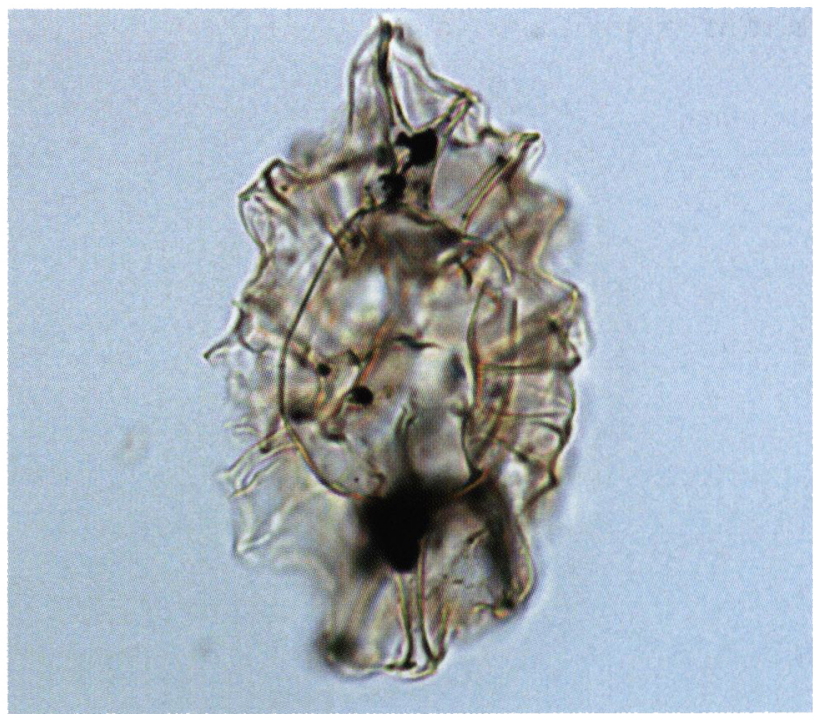

Fig. 9. Ectosphaeropsis burdigalensis. GH 427.7-431.2 m. Overall dimensions $98 \times 56 \mu \mathrm{m}$.

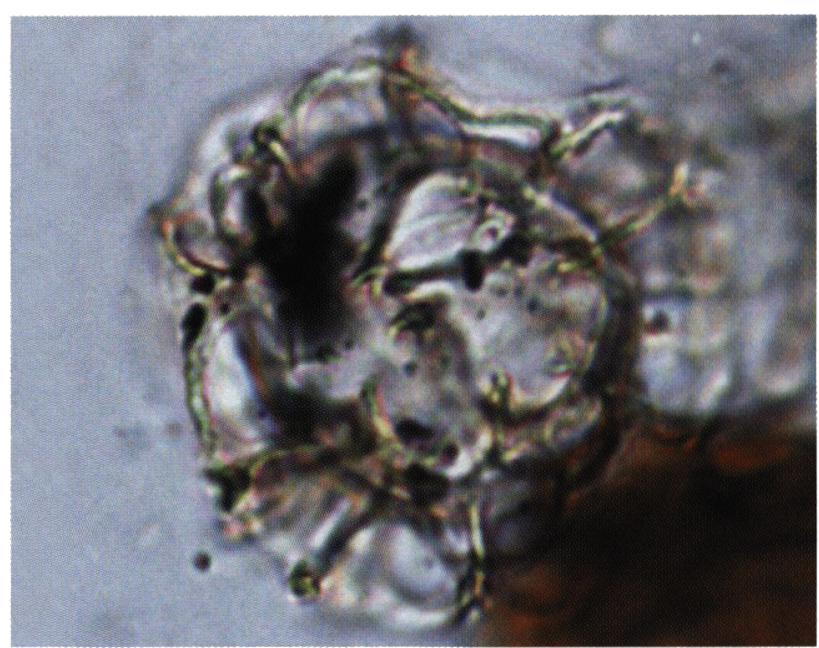

Fig. 11. Unipontidinium aquaeductum. GH 210.3-211.4 m. Central body $32 \times 30 \mu \mathrm{m}$; overall diameter $47 \mu \mathrm{m}$.

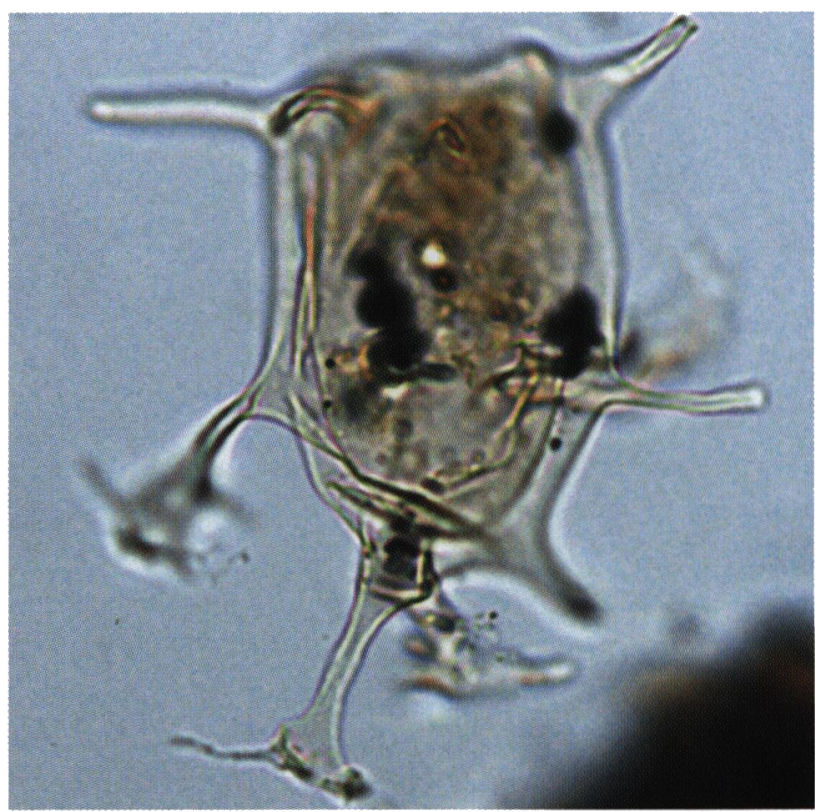

Fig. 13. Distatodinium cavatum. GH 493.4-496.7 m. Endocyst $48 \times 29 \mu \mathrm{m}$; pericyst $51 \times 36 \mu \mathrm{m}$. 


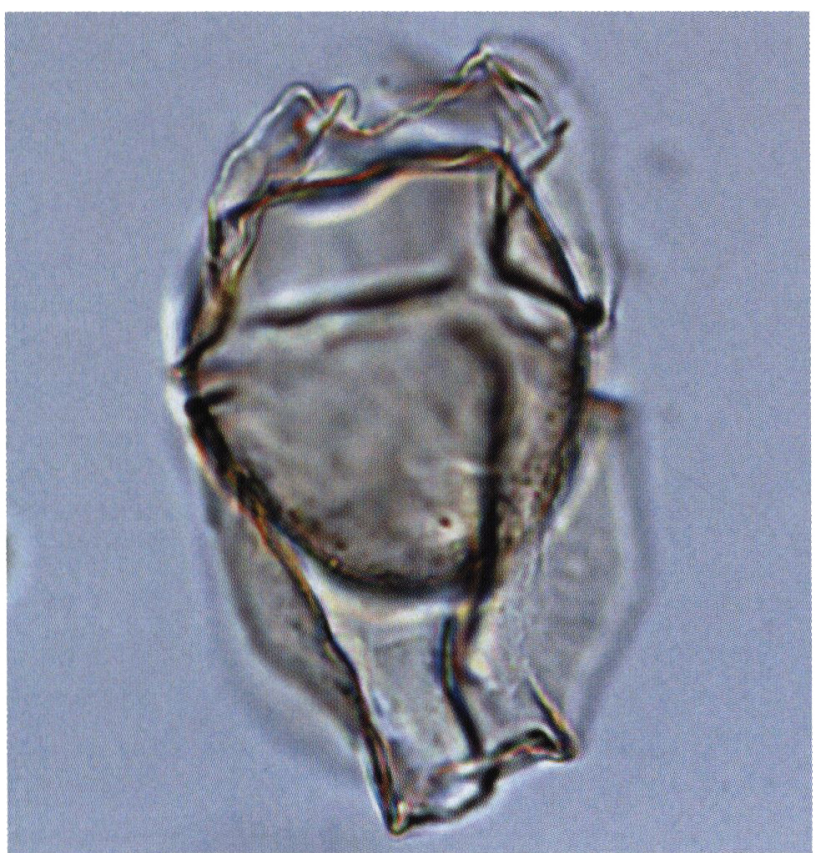

Fig. 14. Hystrichosphaeropsis obscura. GH 397.7-400.7 m. Overall dimensions $84 \times 45 \mu \mathrm{m}$.

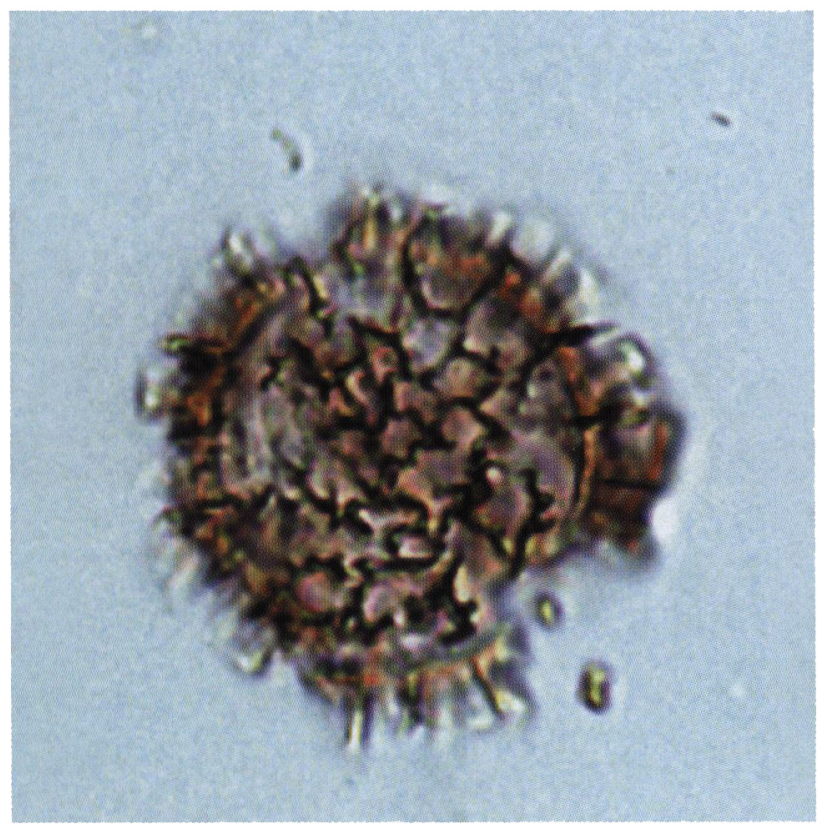

Fig. 16. Labyrinthodinium truncatum subsp. modicum. GH 275.3$278.3 \mathrm{~m}$. Central body diameter $36 \mu \mathrm{m}$.

\section{Age assessment and comparisons with other Northern Hemisphere Neogene dinocyst zonations}

So far, only the studies of Zevenboom and co-workers on the continuous Neogene successions from central and northern Italy provide the single, internally consistent, quasi-continuous dinocyst zonal scheme for the Miocene that has first-order paleomagnetic and biostratigraphic calibration (e.g., Zevenboom et al., 1994; Zevenboom, 1995; 1996, and Montanari et al., 1997).

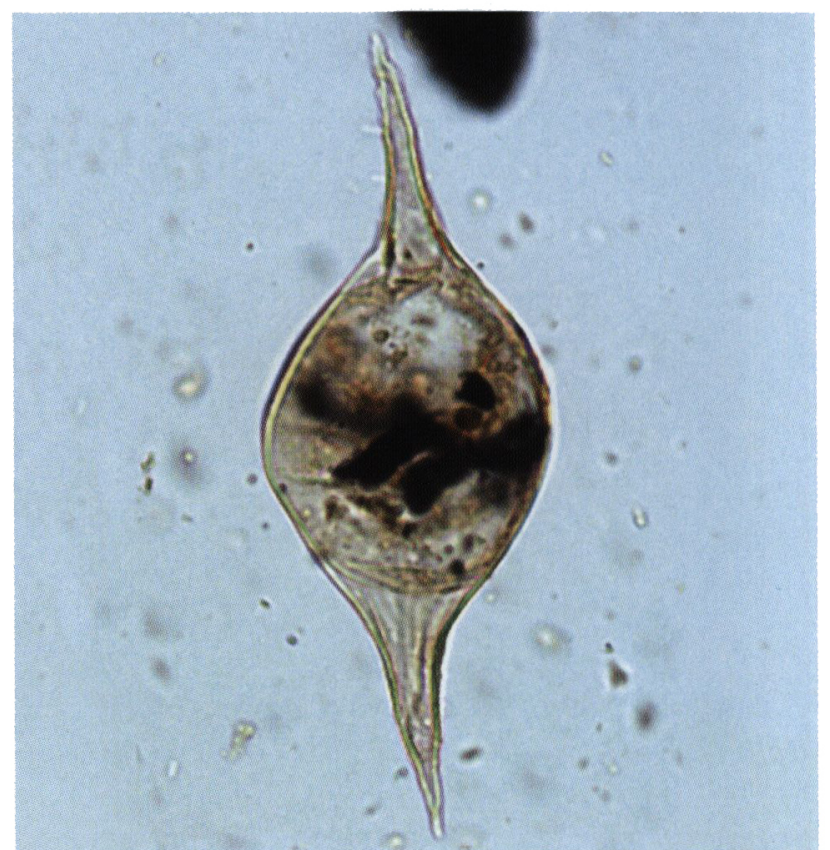

Fig. 15. Palaeocystodinium ventricosum. GH 208.1-210.3 m. Overall dimensions $112 \times 40 \mu \mathrm{m}$.

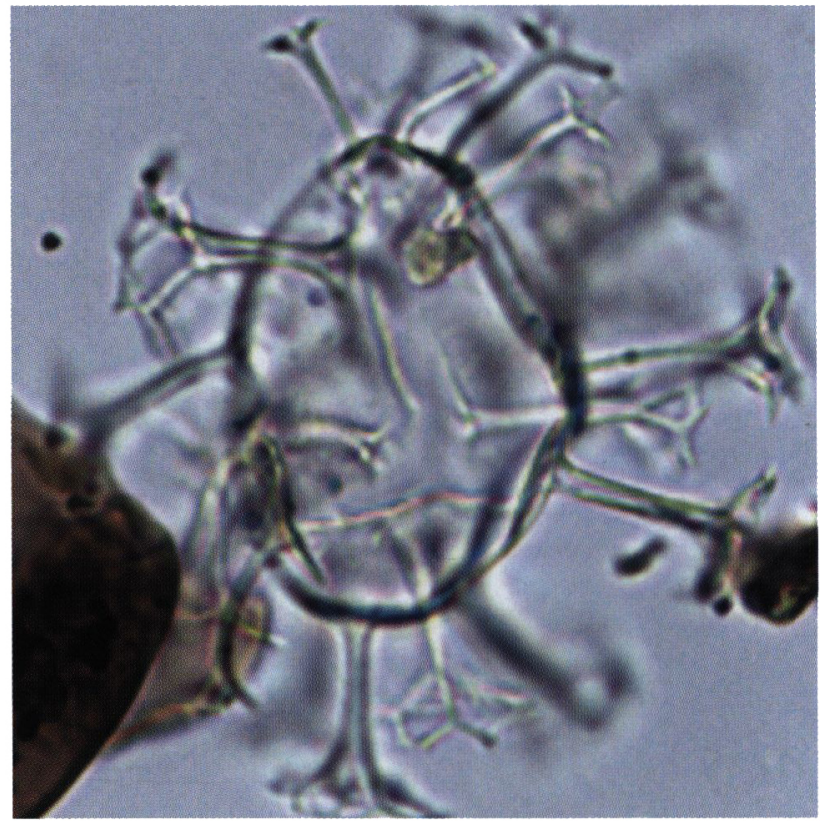

Fig. 17. Achomosphaera andalousiense. GH 110.8-112-8 $\mu \mathrm{m}$. Central body $34 \times 25 \mu \mathrm{m}$; processus $17 \mu \mathrm{m}$.

Although unfortunately large portions of his thesis remain unpublished in the mainstream literature, we principally rely on this work for age-calibration, as indicated above. This despite indications that Cenozoic dinocyst distribution is principally controlled by variations in sea surface temperature, oceanic circulation, and/or differing latitudinal positions (e.g., Brinkhuis et al., 1998, 2003a,b; Sluijs et al., submitted). Since the Mediterranean was strongly influenced by Atlantic circulation throughout the Cenozoic, we consider its dinocyst record to be largely representative for the North 


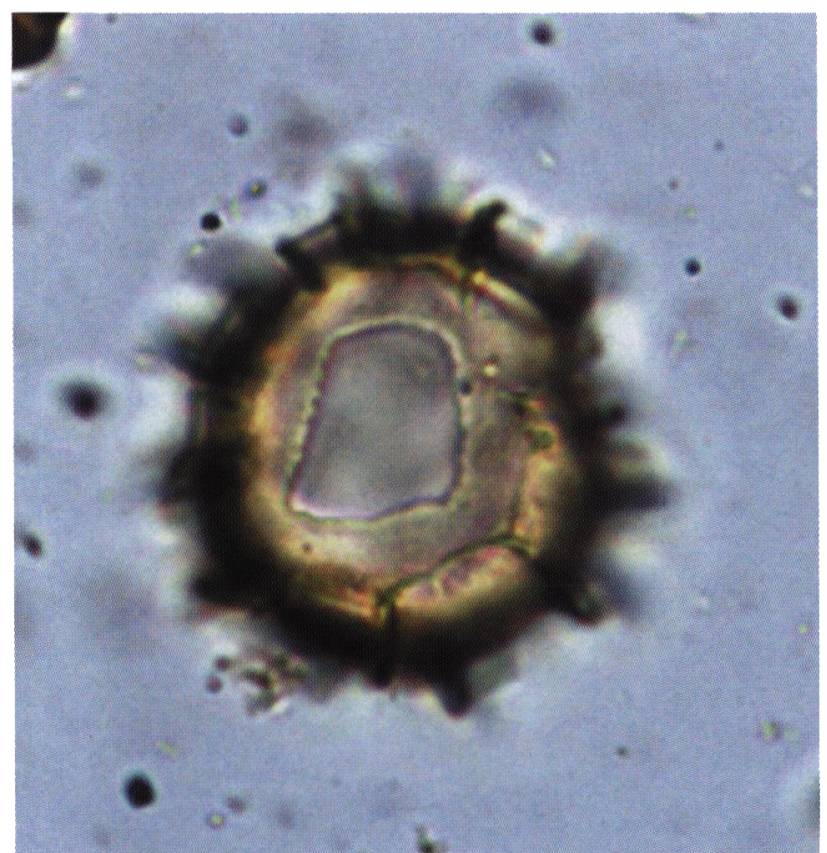

Fig. 18. Cerebrocysta poulsenii. GH 208.1-210.3 m. Overall dimensions $38 \times 35 \mu \mathrm{m}$

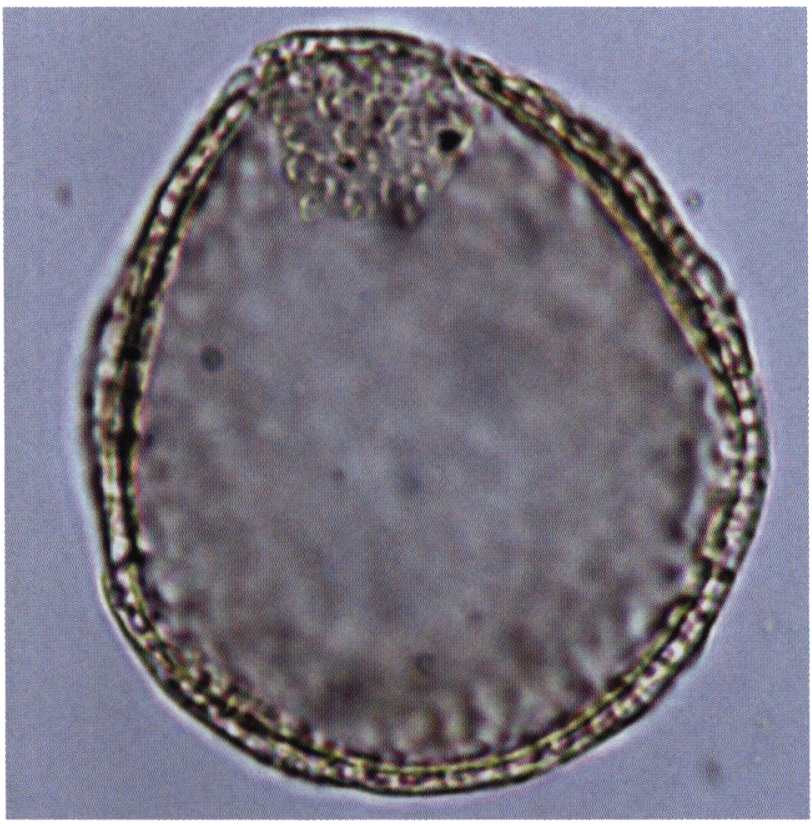

Fig. 20. Gramocysta verricula. GH 166.3-169.3 m. Overall dimensions $70 \times 62 \mu \mathrm{m}$.

Sea Basin as well. We therefore applied Zevenboom's principal findings, but evaluate, and deviate only where indications are that index datums are clearly controlled by the more northern latitudinal position of our study region, in part already discussed above (Fig. 22).

The single other meaningful Miocene zonal scheme is developed for the eastern North Atlantic margin by De Verteuil and Norris (1996). Having a similar latitudinal position as the southern North Sea Basin, the succession of index dinocyst events seems relevant for our study. Yet, De Verteuil and Norris' study suffers

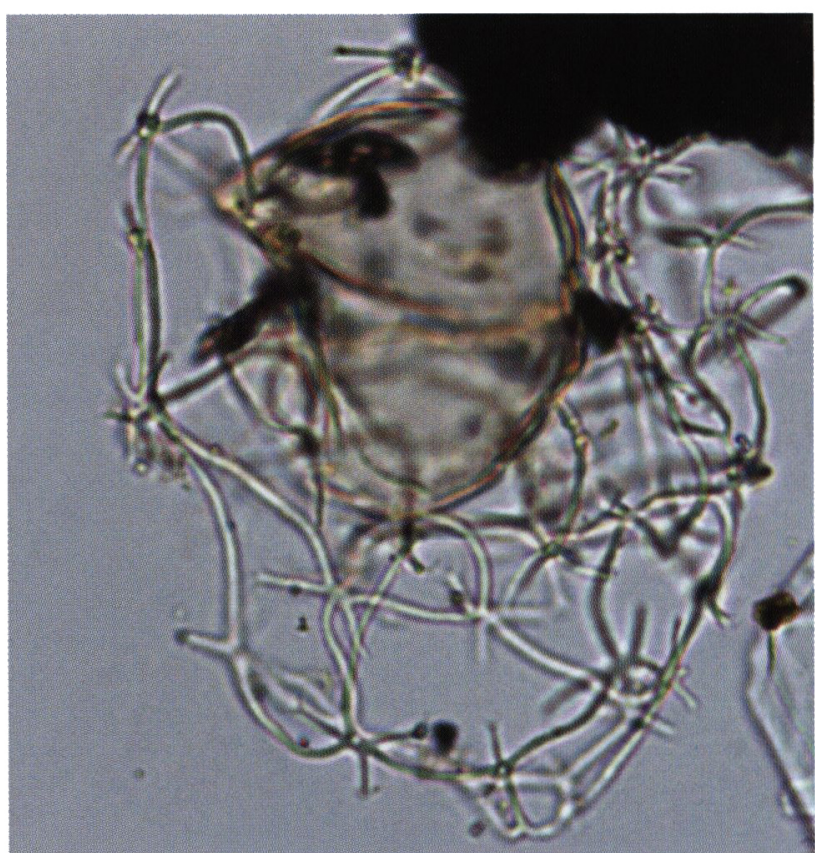

Fig. 19. Cannosphaeropsis passio. GH 159.8-163.3 m. Overall dimensions $81 \times 73 \mu \mathrm{m}$.

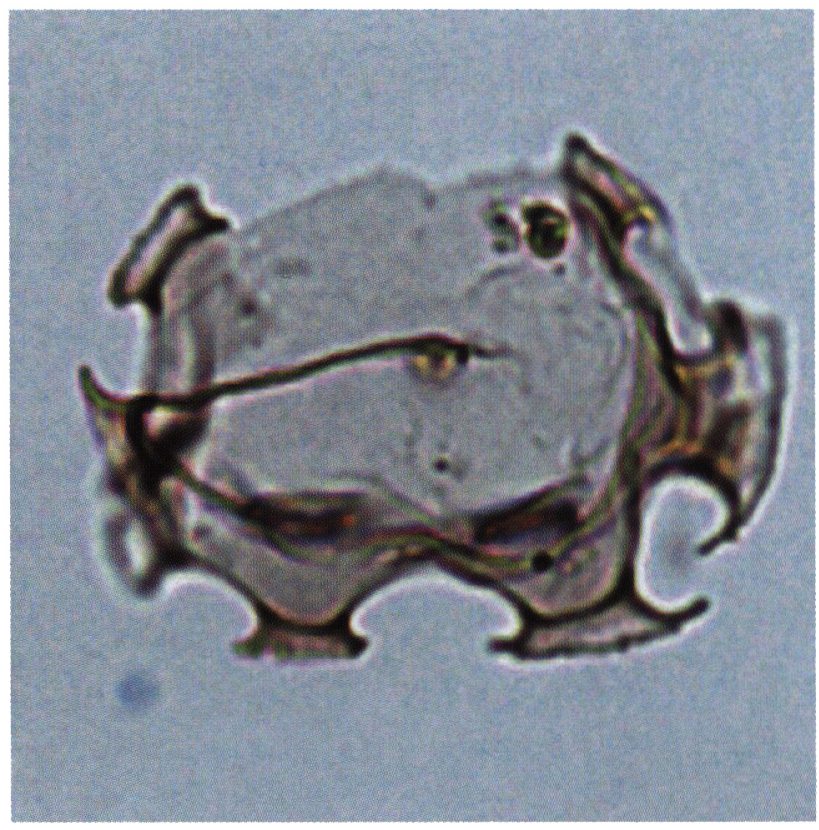

Fig. 21. Selenopemphix armageddonensis. GH 118.8-120.8 m. Cental body diameter $39 \mu \mathrm{m}$.

from poor age calibration. We discuss relationships with these zonal schemes below, involve other studies where relevant, and evaluate our age-assessments for the southern North Sea Miocene zones (Fig 22).

North and central Italy (Zevenboom, 1995)

Most of the index dinocyst events recognized by Zevenboom and co-workers in the central Mediterranean have now also been recorded in the southern North Sea Basin, and are employed in our proposed 
zonal scheme as discussed above. Some events considered in the Mediterranean zonation have however not been adopted here. This in view of e.g., obvious diachronicity (e.g., the LO of Ectosphaeropsis burdigalensis and Mr. picena), and/or obvious strong environmental control over the distribution of certain taxa, in this case mainly oceanic taxa like e.g., Nematosphaeropsis downiei.

Zevenboom (1995) determined a mid-Burdigalian LO of Hystrichosphaeropsis obscura (Fig. 14). Subse-

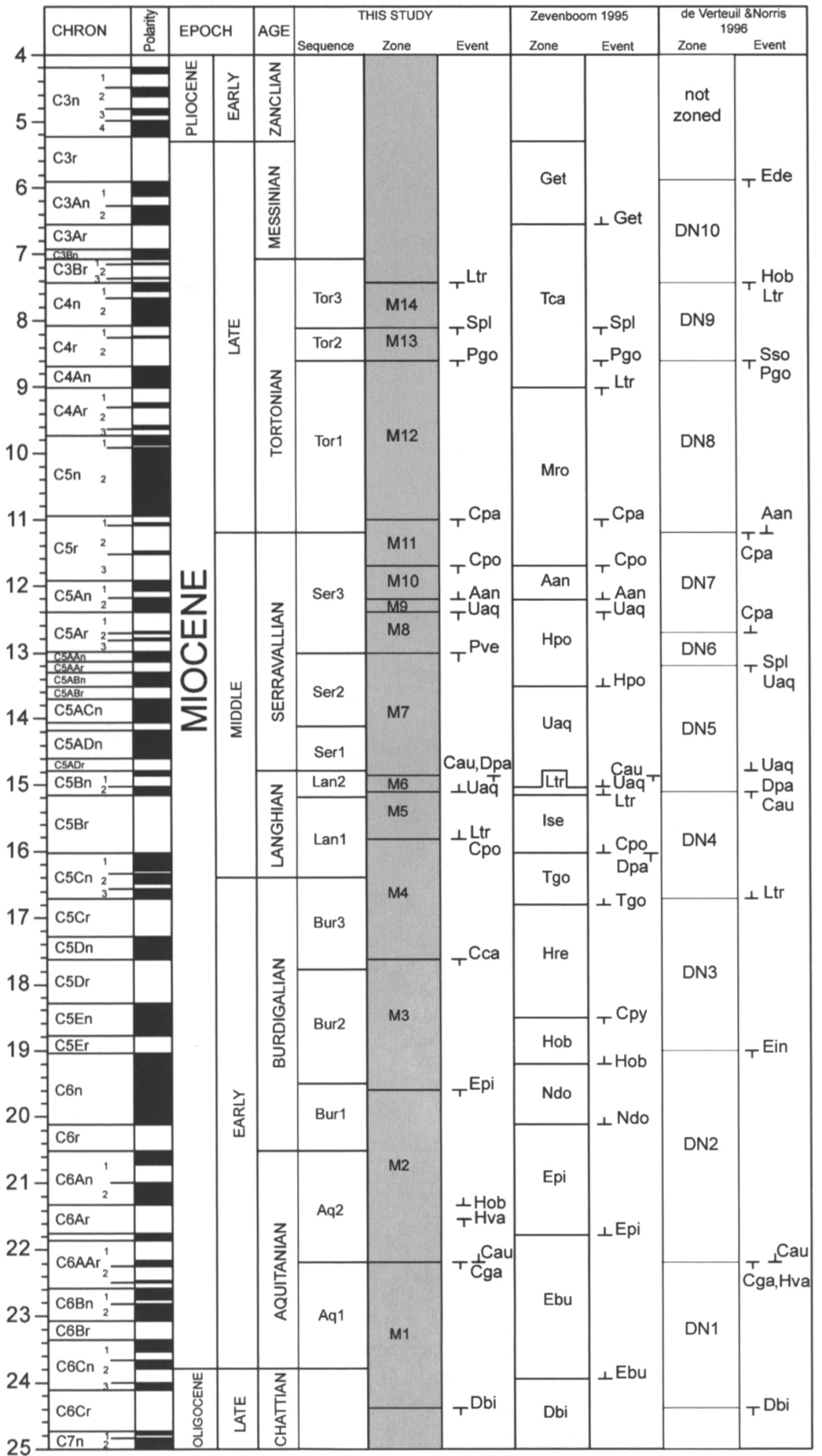

quent studies (Montanari et al., 1997; Coccioni et al., 1997 and Dybkjaer and Rasmussen, 2000) extended its LO to the lower part of the Burdigalian. De Verteuil and Norris (1996) record this taxon down into their DN2, and even questionably into their DN1 Zone. This suggests an Aquitanian LO of $H$. obscura. Our study appears to confirm this aspect, since the event is recorded within the SNSM2 Zone.

Fig. 22. Miocene timescale of Berggren et al. (1995) showing the chronostratigraphic position of the dinocyst zonation of Zevenboom 1995, De Verteuil \& Norris, 1996 and this study. 
The LO of Cousteaudinium aubryae (Thalassiphora gonoperforata nom. nud. Rusbült and Strauss, 1992; Tgo Interval Zone of Zevenboom, 1995) is apparently recorded earlier in the North Sea than in Italy (uppermost Burdigalian; Cortemilia section). In this paper the event is determined in the SNSM2 Zone. This further confirms early appearances reported from in the late Aquitanian in Belgium (Louwye et al, 2000), and Virginia and Maryland (De Verteuil and Norris, 1996).

Contrary to the succession of events in Italy, where Cerebrocysta poulsenii (as 'Imperfectodinium septatum' of Zevenboom, 1995) has an earlier occurrence (LO) than Labyrinthodinium truncatum, in the Netherlands both events coincide. In Nieder Ochtenhausen (Strauss et al., 2001) Labyrinthodinium truncatum apparently even appears before Cerebrocysta poulsenii. The North Sea LO of Labyrinthodinium truncatum appears to correlate with the early Langhian $1 \mathrm{mfs}$ $(\sim 15.8 \mathrm{Ma})$ of Hardenbol et al. (1998; Munsterman, manuscript in preparation). Hystrichosphaeropsis pontiana (Hpo Interval Zone, Zevenboom, 1995) is irregularly present in the Dutch shallow marine settings. The age of the event appears to roughly correspond to that postulated by Zevenboom (1995) for the Mediterranean. The HO of Labyrinthodinium truncatum in the Netherlands (late Tortonian) is apparently younger than in Italy (lower part of subchron C4An, middle Tortonian; Mazzapiedi section, Zevenboom, 1995). The assessment for the southern North Sea Basin is based on the superposition of events and on our classification in sequences (Trt-3; internal RGD, NITG-TNO, LPP reports; Munsterman, manuscript in preparation). Galeacysta etrusca (base Get Interval Zone, Zevenboom 1995) is absent in the marine associations of the Netherlands.

\section{Eastern North Atlantic margin (De Verteuil and Norris, 1996)}

De Verteuil and Norris (1996) described ten informal dinocyst zones for the Miocene coastal plain sediments of the Salisbury Embayment (Maryland and Virginia). The chronostratigraphic assessment of their zones is indirectly based on sparce records of calcareous nannofossils and planktonic foraminifers. Approximately half of the dinocyst events used to define their zones are also applied in our study. The chronostratigraphic datums for the $\mathrm{HO}$ of Distatodinium biffii and the $\mathrm{HO}$ of Chiropteridium galea in the Netherlands are in accordance with those from the mid-Atlantic margin (DN1 Zone, De Verteuil and Norris, 1996).

The HO of Exochosphaeridium insigne (DN2, De Verteuil and Norris, 1996) is not applied here, because the taxon is infrequently present in Dutch wells from the late Aquitanian to the Burdigalian. On the other hand Membranilarnacia? picena is not discerned at the eastern Atlantic margin. The LO of Cousteaudinium aubryae in the southern North Sea matches that of the eastern Atlantic margin. In the study of De Verteuil and Norris (1996) the LO of Cousteaudinium aubryae (Fig. 10) and the $\mathrm{HO}$ of Homotryblium vallum coincide. Our results from the Dutch wells argue for a slightly younger chronostratigraphic position in the Aquitanian for the $\mathrm{HO}$ of Homotryblium vallum (Fig. 22). The genus Homotryblium is known to be strongly environmentally controlled (e.g. Brinkhuis, 1994; Dybkjaer, 2004).

Cordosphaeridium cantharellum (= Tityrosphaeridium cantharellus sensu Williams et al., 1998) has a consistent HO in the Dutch part of the North Sea (SNSM 3 Zone, Bur-3 sequence). There is some uncertainty regarding the chronostratigraphic position of the $\mathrm{HO}$ of this taxon in different North Atlantic and adjacent basins (De Verteuil and Norris, 1996). The last occurrence in the North Sea is younger than that reported from the eastern Atlantic margin, and seems to match the magnetically calibrated event in North Italy (top C5Dr; Zevenboom, 1995).

The LO of Labyrinthodinium truncatum is discussed in the remarks on zone SNSM 5 above. In Dutch, German and U.S. studies the HO of Cousteaudinium aubryae and Distatodinium paradoxum (DN 4 Zone in De Verteuil and Norris, 1996) appear to coincide, marking the top of the Langhian. In the southern North Sea area the HO of Cousteaudinium aubryae is chosen for definition of the SNSM6 zone, because this event appears more consistent than the $\mathrm{HO}$ of Distatodinium paradoxum (Fig. 12). De Verteuil and Norris (1996) and Strauss et al. (2001) present the HO of Distatodinium paradoxum as being older than the LO of Unipontidinium aquaeductum. In the Dutch (this study), Belgian (Louwye et al., 2000) southern North Sea and Norwegian-Greenland Sea (Poulsen et al., 1996) an overlap in both ranges has however been demonstrated. The LO of Unipontidinium aquaeductum in the southern North Sea fits well with the position of the event as reported by Zevenboom (1995) in the Uaq Interval Zone of the Cessole section, N-Italy and is calibrated against the upper part of $\mathrm{C} 5 \mathrm{Bn} 2 \mathrm{n}$.

The HO of Systematophora placacantha (top DN5 Zone) is interpreted by De Verteuil and Norris (1996) to mark the 'middle Serravallian'. Post DN5 Zoneoccurrences are interpreted as reworked specimens. A comparable distribution pattern is recorded in NW Germany (Strauss et al., 2001). In borehole Nieder Ochtenhausen the HCO of Systematophora placacantha 
concurs with the HO of Unipontidinium aquaeductum. Rare higher occurrences reach into the Late Miocene Spiniferites pseudofurcatus Subzone (Strauss et al., 2001). In the Dutch wells a continuous record is found at least up to the SNSM11 Zone (earliest Tortonian). Systematophora placacantha becomes less frequent in the SNSM 12 and 13 zones ('middle' Tortonian). In Belgian wells the taxon regularly appears in low abundances in the early Tortonian (Louwye, 2002). Zevenboom (1995) demonstrated a continuous record of Systematophora placacantha into his Impagidinium strialatum Subzone, the upper part of his Trinovantedinium capitatum Interval Zone at the Mazzapiedi section, $\mathrm{N}$ Italy. The event is estimated to mark the $\mathrm{C} 4 \mathrm{r} / \mathrm{C} 4 \mathrm{n}$ transition. The result of the present study is congruent with the Italian record.

The HO of Unipontidinium aquaeductum at the Venlo Block (SE part of the Netherlands) is apparently slightly younger than that reported for the eastern Atlantic margin. The timing of the event corresponds with the calibrated $\mathrm{HO}$ of this taxon in $\mathrm{N}$ Italy. Zevenboom (1995) correlated the HO of Unipontidinium aquaeductum to the base of C5An $(\sim 12.4 \mathrm{Ma})$. Achomosphaera andalousiensis has an earlier LO (SNSM10 Zone; late Serravallian) in the southern North Sea (Köthe, 2000; Strauss et al., 2001; this study) and in Italy (Zevenboom, 1995) compared to that at the eastern Atlantic margin (earliest Tortonian). The $\mathrm{HO}$ of Cerebrocysta poulsenii (top SNSM 10 Zone, this study) falls within the late Serravallian like in Germany (Strauss et al., 2001) and in Italy (Zevenboom, 1995). De Verteuil and Norris (1996) however, report sporadic appearances in the early Tortonian. The presence of Cannosphaeropsis passio is indicative of an age close to or at the Serravallian-Tortonian boundary. Its distribution marks the DN7 dinoflagellate cyst zone of De Verteuil and Norris (1996) at the top of the Serravallian. The results of Strauss et al. (2001) are congruent with this record. Zevenboom (1995), records Cannosphaeropsis passio in the Mazzapiedi section of Italy just after the significant sealevel fall at the Serravallian-Tortonian boundary (top subchron C5r). Dutch dinocyst associations from the southern North Sea confirm the HO of Cannosphaeropsis passio after the prominent sealevel fall, being recorded in the Trt-1 TST (top SNSM 11 Zone). This minor difference may be attributed to reworking of the older late Serravallian successions or local erosion of early Tortonian deposits.

The highest occurrence of Palaeocystodinium golzowense in the present study (top SNSM12 Zone) is in agreement with the records of both Zevenboom (1995) and De Verteuil and Norris (1996). The HO of Sumatradinium soucouyantiae (top DN 8 Zone of De Verteuil and Norris, 1996) has not been used in our study. Its last common occurrence is recorded in the SNSM11 Zone. The taxon appears infrequently in the SNSM 12 and SNSM 13 zones. The distribution of Sumatradinium soucouyantiae is clearly environmentally controlled, favouring (sub)tropical, nutrient-rich watermasses.

The $\mathrm{HO}$ of Hystrichosphaeropsis obscura (top DN 9 Zone of De Verteuil and Norris, 1996) in the Tortonian conficts with Early Pliocene occurrences from Dutch wells. A younger occurrence, e.g., in the latest Miocene, Messinian, was also shown by Zevenboom (1995). Lund and Heilmann-Clausen (1999) consider the $\mathrm{HO}$ of Hystrichosphaeropsis obscura (top Amiculosphaera umbracula Zone) in Wursterheide and Nieder Ochtenhausen to also be doubtful for the reason that the top might be truncated by the Quaternary transgression. The $\mathrm{HO}$ of Labyrinthodinium truncatum, as calibrated against the top of Chron C4n (De Verteuil and Norris, 1996) seems to fit the position in the Dutch wells. Finally, Erymnodinium delectabile, an index species for the top of DN10 Zone of De Verteuil and Norris (1996) has not been recognized in the studied wells from the Netherlands.

\section{Concluding remarks}

Recent drilling of the relatively well-developed Dutch marginal marine Miocene successions provided an opportunity to establish a first-ever dinocyst zonation for this region. Recognition of consistent dinocyst events between multiple boreholes allow to propose fourteen zones for the Miocene of the southern North Sea Basin, tied to the Breda Formation. By combining information from calcareous microfossils, sequence stratigraphic analysis, and previous dinocyst studies from the Mediterranean and the eastern Atlantic margin, a meaningful age-model has been developed for the Breda Formation for the first time.

This study represents but a first step; follow up investigations are currently in progress. Manuscripts focusing on the quantitative dinocyst distribution patterns, other palynomorphs, taxonomy, paleoecology, and e.g., the sequence stratigraphic framework are now being completed. With rich palynological assemblages containing besides dinocysts also e.g., abundant sporomorphs, the Neogene of the southern North Sea Basin constitutes an important sedimentary archive. Further study will allow detailed reconstruction of the response of Northern Hemisphere, mid latitude shallow marine systems to Neogene Global Change, potentially also including recognition of coeval terrestrial climate change. 


\section{Acknowledgements}

The authors want to express their gratitude to D. Zevenboom and S. Kerstholt (TNO-NITG) for their pleasant co-operation in the palynological analysis. S. Louwye (University of Gent, Belgium), S. Van Simaeys (University of Leuven, Belgium) and G.L. Williams (Atlantic Geoscience Centre, Canada) are acknowledged for constructive discussions on the taxonomy and chronostratigraphy of dinoflagellate cysts. G.F.W. Herngreen (University of Utrecht = UU) and C.J. van der Zwan (Shell, UU) are thanked for their reviews improving the manuscript. L. Bik (UU) and R. Verreussel (TNO-NITG) are thanked for their assistence with the figures. Our appreciation also goes out to G. Dammers (TNO-NITG), J. van Tongeren (UU) and N. Welters (UU) for help in processing the samples. This is NSG contribution no. 20040304

\section{References}

Benedek, P.N., 1972. Phytoplanktonten aus dem Mittel - und Oberoligozän von Tönisberg (Niederrheingebiet). Palaeontogr. Abt. B, 137 (1-3): 1-71.

Berggren, W.A., Kent, D.V., Swisher, III, C.C. \& Aubrye, M.-P., 1995. A revised Cenozoic geochronology and chronostratigraphy. In: Berggren, W.A., Kent, D.V., Aubrye, M.-P. \& Hardenbol, J. (eds). Geochronology, time scales and global stratigraphic correlation. Soc, Econ. Paleontol. Mineralog., Special Publ., 54: 129-212.

Biffi, U. \& Manum, S.B., 1988. Late Eocene - Early Miocene dinoflagellate cyst stratigraphy from the Marche Region (central Italy). Boll. Soc. Paleontol. Ital., 27 (2): 163-212.

Brinkhuis, H., 1992. Late Eocene to Early Oligocene dinoflagellate cysts from central and northeast Italy. Ph. D. Diss. Univ. Utrecht: $169 \mathrm{pp}$.

Brinkhuis, H., 1994. Late Eocene to Early Oligocene dinoflagellate cysts from the Priabonian type-area (Northeast Italy): biostratigraphy and paleoenvironmental interpretation. Palaeogeogr., Palaeoclimat., Palaeoecol., 107: 121 - 163.

Brinkhuis, H. Powell, J. \& Zevenboom, D., 1992. High-resolution dinoflagellate cyst stratigraphy of the Oligocene/Miocene transition interval in northwest and central Italy. In: Head, M.J. and Wrenn, J.H., Neogene and Quaternary dinoflagellate cysts and acritarchs. Amer. Ass. Strat. Palynol. Found.: $219-258$.

Brinkhuis, H., Munsterman, D.K., Sengers, S. Sluijs, A., Warnaar, J. \& Williams, G.L., 2003a. Late Eocene-Quaternary dinoflagellate cysts from ODP Site 1168, off western Tasmania. In: Exon, N.F., Kennett, J.P. \& Malone, M.J. (eds), Proc. ODP, Sci. Results, 189 [Online]. Available from World Wide Web: http://www.odp.tamu.edu/publications/189_SR/105/105.htm.

Brinkhuis, H., Sengers, S., Sluijs, A, Warnaar, J. \& Williams, G.L., 2003b. Latest Cretaceous to earliest Oligocene, and Quaternary dinoflagellate cysts from ODP Site 1172, East Tasman Plateau. In: Exon, N.F., Kennett, J.P. \& Malone, M.J. (eds), Proc. ODP, Sci. Results, 189 [Online]. Available from World WideWeb: http://www.odp.tamu.edu/publications/189_SR/106/106.htm.
Coccioni, R., Montanari, A., Fornaciari, E., Rio, D. \& Zevenboom, D., 1997. Potential integrated stratigraphy of the Aquitanian to upper Burdigalian section at Santa Croce di Arcevia (NE Apennines, Italy). In: Montanari, A. et al. (eds). Developments Palaeontol. Stratigr. 15: 279-295.

Doppert, J.W.C., Ruegg, G.H.J., Van Staalduinen, C.J., Zagwijn, W.H. \& Zandstra, J.G., 1975. Formaties van het Kwartair en het Boven-Tertiair in Nederland. In: Zagwijn, W.H. \& Van Staalduinen (eds): Toelichting bij geologische overzichtskaarten van Nederland, RGD: 11-56.

Dybkjær, K., 2004. Morphological and abundance variations in Homotryblium-cyst assemblages related to depositional environments; uppermost Oligocene-Lower Miocene, Jylland, Denmark. Palaeogeogr., Palaeoclim., Palaeoecol., 206: 41-58.

Dybkjær, K. \& Rasmussen, E.S., 2000. Palynological dating of the Oligocene - Miocene successions in the Lille Bælt area, Denmark. Bull. Geol. Soc. Denmark, 47: 87-103.

Geluk, M.C., 1990. The Cenozoic Roer Valley Graben, southern Netherlands. Meded. Rijks Geol. Dienst, 44(4): 63-72.

Geluk, M.C., Duin, E.J.T., Dusar, M., Rijkers, R.H.B., Van den Berg, M.W. \& Van Rooijen, P., 1994. Stratigraphy and tectonics of the Roer Valley Graben. Geol. Mijnb. 73: 129-141.

Gerlach, E., 1961. Mikrofossilien aus dem Oligozän und Miozän Nordwestdeutschlands, unter besonderer Berücksichtigung der Hystrichosphaeren und Dinoflagellaten. N. Jb. Geol. Palaont., Abh, 112 (2): 143-228.

Gliese, J. \& Hager, H., 1978. On browncoal resources in the Lower Rhine Embayment (West Germany). Geol. en Mijnb. 57(4): 517-525.

Hardenbol, J., Thierry, J., Farley, M.B., Jacquin, T, De Graciansky, P.-C. \& Vail, P., 1998. Mesozoic and Cenozoic sequence chronostratigraphic framework of European Basins, Mesozoic and Cenozoic sequence chronostratigraphic chart 1. In: Graciansky de, P.-C. et al. Mesozoic and Cenozoic sequence stratigraphy of European basins. SEPM Spec. Publ. 60.

Head, M.J., 1998. Marine environmental change in the Pliocene and early Pleistocene of eastern England: the dinoflagellate evidence reviewed. In: Van Kolfschoten, Th. And Gibbard, P.L. The dawn of the Quaternary. Meded. NITG-TNO 60: 199-225.

Head, M.J., Norris, G. \& Mudie, P.J., 1989. Palynology and dinocyst stratigraphy of the Upper Miocene and lowermost Pliocene. Proc. Ocean Drill. Progr., Scient. Res. 105: 423-451.

Herngreen, G.F.W., 1987. Correlation between Miocene beds of the SE Netherlands and Italy based on dinoflagellate biozonation. Meded. Werkgr. Tert. Kwart. Geol. 24 (1-2): 31-40.

Köthe, A., 2000. Dinozysten der Pritzierer Schichten in der Bohrung Lübtheen 27/82. Schriftenr. F. Geowiss., 11: 157-179.

Lentin, J.K., 1993. The stratigraphic importance of species of Sumatradinium, Barssidinium, and Erymnodinium, Neogene dinoflagellate genera from offshore eastern Canada. Geol. Surv. of Canada Contr. 42292: 567-582.

Letsch, W.J. \& Sissingh, W. 1983. Tertiary stratigraphy of the Netherlands. Geol. en Mijnb., 62(2): 305-318.

Lippolt, H.J., 1983. Distribution of vulcanic activity in space and time. In: Fuchs, K. et al., Plateau uplift, the Rhenish Shield: 112-120.

Londeix, L. \& Jan du Chêne, R., 1988. Ectosphaeropsis, nouveau genre de dinoflagellé de la region stratotypique du Burdigalien Bordelais (France). Bull. Centres Rech. Explor. - Prod. Elf Aquitaine, 12(1): 251-265.

Louwye, S., 1999. New species of organic-walled dinoflagellates and acritarchs from the Upper Miocene Diest Formation, northern Belgium (southern North Sea Basin). Rev. Palaeobot. Palynol. 107: 109-123. 
Louwye, S., 2000. Dinoflagellate cyst and acritarchs from the Miocene Zonderschot Sands, northern Belgium: stratigraphic significance and correlation with contiguous areas. Geol. Belg. 3/1-2: 55-65.

Louwye, S., 2002. Dinoflagellate cyst biostratigraphy of the Upper Miocene Deurne Sands (Diest Formation) of northern Belgium, southern North Sea Basin. Geol. J. 37: 55-67.

Louwye, S. \& Laga, P., 1998. Dinoflagellate cysts of the shallow marine Neogene succession in the Kalmthout well, northern Belgium. Bull. Geol. Denmark 45: 73-86.

Louwye, S., De Coninck, J. \& Verniers, J., 1999. Dinoflagellate cyst stratigraphy and depositional history of Miocene and Lower Pliocene formations in northern Belgium (southern North Sea Basin). Geol. en Mijnb. 78: 31-46.

Louwye, S., De Coninck, J. \& Verniers, J., 2000. Shallow marine Lower and Middle Miocene deposits at the southern margin of the North Sea Basin (northern Belgium): dinoflagellate cyst biostratigraphy and depositional history. Geol. Mag. 137(4): 381-394.

Lund, J.J. \& Heilmann-Clausen, C., 2001. Dinoflagellate correlation between the research boreholes Nieder Ochtenhausen and Wusterheide, Miocene, NW Germany. Aardk. Mededel. 11: 51-60.

Manum, S.B., Boulter, M.C., Gunnarsdottir, H., Rangnes, K. \& Scholze, A., 1989. Eocene to Miocene palynology of the Norwegian Sea (ODP Leg 104). Proc. Ocean Drill. Progr., Scient. Res. 104: 611-662.

Montanari, A., Bice, D.M., Capo, R., Coccioni, R., Deino, A., DePaolo, D.J., Emmanuel, L., Monechi, S., Renard., M. \& Zevenboom, D., 1997. Integrated stratigraphy of the Chattian to mid-Burdigalian pelagic sequence of the Contessa Valley (Gubbio, Italy). In: Montanari, A. et al. (eds). Developments Palaeontol. Stratigr. 15: 249-277.

Morgenroth, P., 1966. Neue in organischer Substanz erhaltene Mikrofossilien des Oligozans. N. Jb. Geol. Palaont. Abh. 127(1): 1-12.

Mudie, P.J., 1989. Palynology and dinocyst biostratigraphy of Late Miocene to Pleistocene, Norwegian Sea: ODP Leg 104, sites 642 to 644. Proc. Ocean Drill. Progr., Scient. Res., 104: 587-610.

NAM and RGD, 1980. Stratigraphic Nomenclature of the Netherlands. Verhandelingen KNGMG 32: 77 pp.

Piasecki, S., 1980. Dinoflagellate cyst stratigraphy of the Miocene Hodde and Gram formations, Denmark. Bull. Geol. Soc., Denmark 29: 53-76.

Poulsen, N.E., Manum, S.B., Williams, G.L. \& Ellegaard, M., 1996. Tertiary dinoflagellate biostratigraphy of Sites 907,908 and 909 in the Norwegian-Greenland Sea. Proceedings ODP Scientific Results 152: 255-287.

Powell, A.J., 1986. Latest Palaeogene and earliest Neogene dinoflagellate cysts from the Lemme section, northwest Italy. AASP Contr. Ser. 17: 83-104.

Powell, A.J., 1992. Dinoflagellate cysts of the Tertiary System. In: Powell, A.J. (ed), A stratigraphic index of dinoflagellate cysts: 155-272.

Reichart \& Brinkhuis, 2003. Late Quaternary Protoperidinium cysts as indicators of paleoproductivity in the northern Arabian Sea. Marine Micropaleontology 49: 303-315.

Rooijen van P., Klostermann, J., Doppert, J.W.Chr., Rescher, C.K., Verbeek, J.W., Sliggers, B.C. \& Glasbergen, P., 1984. Stratigraphy and tectonics in the Peel-Venlo area as indicated by Tertiary sediments in Broekhuizenvorst and Geldern-T1 boreholes. Meded. Rijks Geol. Dienst 38(1): 1-27.
Rossa, H.G., 1986. Upper Cretaceous and Tertiary inversion tectonics in the western part of the Rhenish-Westphalian coal district (FRG) and in the Campine area (N. Belgium). Ann. Soc. Geol. Belgique 109: 367-410.

Sarjeant, W.A.S., 1984. Re-study of some dinoflagellate cysts from the Oligocene and Miocene of Germany. J. micropalaeontol. 3(2): 73-94.

Sissingh, W., 2003. Tertiary paleogeographic and tectonostratigraphic evolution of the Rhenish Triple Junction. Palaeogeogr., Palaeoclim., Palaeoecol. 196(1-2): 229-263.

Sluijs, A., Brinkhuis, H., Stickley, C.E., Warnaar, J., Williams, G.L. \& Fuller, M., 2003. Dinoflagellate cysts from the Eocene-Oligocene transition in the Southern Ocean: results from ODP Leg 189. In: Exon, N.F., Kennett, J.P., \& Malone, M.J. (eds), Proc. ODP, Sci. Results, 189 [Online]. Available from World Wide Web: http://www.odp.tamu.edu/publications/189_SR/104/104.htm.

Stover, L.E. \& Hardenbol, J., 1993. Dinoflagellates and depositional sequences in the Lower Oligocene (Rupelian) Boom Clay Formation, Belgium. Bull. Soc. Belge Geol. 102(1-2): 5-77.

Stover, L.E., Brinkhuis, H., Damassa, S.P., De Verteuil, L., Helby, R.J., Monteil, E., Partridge, A.D., Powell, A.J., Riding, J.B., Smelror, M. \& Williams, G.L. 1996. Mesozoic-Tertiary dinoflagellates, acritarchs and prasinophytes. In: Jansonius, J. \& McGregor, D.C. (eds), Palynology: principles and applications. Am. Ass. Strat. Palynol. Found. (2): 64-750.

Strauss, C. \& Lund, J.J., 1992. A Middle Miocene dinoflagellate cyst microflora from Papendorf near Hamburg, Germany. Mitt. Geol.-Palaont. Inst. Univ. Hamburg 73: 159-189.

Strauss, C. Lund, J.J. \& Lund-Christensen, J., 2001. Miocene dinoflagellate cyst biostratigraphy of the Nieder Ochtenhausen Research Borehole. Geol. Jahrb. A 152.

Teichmüller R., 1972. Die tektonische Entwicklung der Nederrheinischen Bucht. In: Illies, J.H., Fuchs, K. (eds). Approaches to Taphrogenesis: 269-285.

Utescher, T., Mosbrugger, V. \& Ashraf, A.R., 2000. Terrestrial climate evolution in Northwest Germany over the last 25 million years. Palaios, 15: 430-449.

Van Adrichem Boogaert, A.H. \& Kouwe, W.F.P. (eds), 1993-1997. Stratigraphic Nomenclature of the Netherlands, revision and update by RGD and NOGEPA. Meded. Rijks Geol. Dienst 50, section I: $39 \mathrm{pp}$.

Van den Berg, M.W., 1994. Neotectonics of the Roer Valley rift system. Style and rate of crustal deformation inferred from syntectonic sedimentation. Geol. en Mijnb. 73: 143-156.

Van den Berg, M.W., 1996. Fluvial sequences of the Maas: a $10 \mathrm{Ma}$ record of neotectonics and climate change at various time-scales. Ph. D. Diss. Agricult. Univ. Wageningen: 181 pp.

Van den Bosch, M., Cadee, M.C. \& Janssen, A.W., 1975. Lithostratigraphical and biostratigraphical subdivision of Tertiary deposits (Oligocene-Pliocene) in Winterswijk-Almelo region (eastern part of the Netherlands). Scripta Geol. 29: 1-121.

Van Simaeys, S., Munsterman, D.K. \& Brinkhuis, H., 2004. Oligocene dinoflagellate cyst biostratigraphy of the southern North Sea Basin. In: Van Simaeys, S. Stratigraphic and paleoenvironmental analysis of the Rupelian and Chattian in their type regions: implications for global Oligocene chronostratigraphy. Ph. D. Diss. Univ. Leuven: 57-81.

Van Simaeys, S., Munsterman, D.K. \& Brinkhuis, H., submitted. Oligocene dinoflagellate cyst biostratigraphy of the southern North Sea Basin. Rev. Palaeobot. Palynol. 
Verbeek, J.W., de Leeuw, C.S., Parker, N. \& Wong, Th.E., 2002. Characterisation and correlation of Tertiary seismostratigraphic units in the Roer Valley Graben. Netherl. Journ. Geosc. 81(2): 159-166.

Versteeg, G.J.M. \& Zevenboom, D. 1995. New genera and species of dinoflagellate cysts from the Mediterranean Neogene. Rev. Palaeobot. Palynol. 85: 213-229.

Verteuil de L. \& Norris, G., 1992. Miocene Protoperidiniacean dinoflagellate cysts from the Maryland and Virginia coastal plain. In: Head, M.J. \& Wrenn, J.H. (eds), Neogene and Quaternary dinoflagellate cysts and acritarchs. Amer. Ass. Strat. Palynol. Found.: 391-430.

Verteuil de L. \& Norris, G., 1996. Miocene dinoflagellate stratigraphy and systematics of Maryland and Virginia. Micropaleontol. 42: $172 \mathrm{pp}$.

Vinken, R. (ed), 1988. The Northwest European Tertiary Basin. Results of the International Geological Correlation Program 124. Geol. Jb. A-100: 508 pp.

Williams, G.L., Lentin, J.K. \& Fensome, R.A., 1998. The Lentin and Williams index of fossil dinoflagellates 1998 edition. AASP Contr. Ser. 24: 817 pp.

Williams, G.L. \& Manum, S.B., 1999. Oligocene - Early Miocene dinocyst stratigraphy of hole 985A (Norwegian Sea). Proc. Ocean Drill. Progr., Scient. Res. 162: 99-109.

Williams, G.L., Brinkhuis, H., Fensome, R.A., Pearce, M.A. \& Weegink, J.W., 2004. Southern Ocean and global dinoflagellate cysts compared. Index events for the Late Cretaceous-Neogene, In: Exon, N.F., Kennett, J.P., Malone, M.J., (Eds.). Proc. ODP, Scient. Res. 189
Wilpshaar, M., Santarelli, A., Brinkhuis, H., \& Visscher, H., 1996. Dinoflagellate cysts and mid - Oligocene chronostratigraphy in the central Mediterranean region. Journ. Geol. Soc., (London) 153: 553-561.

Zagwijn, W.H., 1989. The Netherlands during the Tertiary and Quarternary: a case history of Coastal Lowland evolution. Geol. en Mijnb. 68: 107-120.

Zevenboom, D., Brinkhuis, H. \& Visscher, H., 1994. Dinoflagellate cysts palaeoenvironmental analysis of the Oligocene/Miocene transition in northwest and central Italy. Giorn. di Geol. 56(1), 3a: $155-169$

Zevenboom, D., 1995. Dinoflagellate cysts from the Mediterranean Late Oligocene and Miocene. Ph.D. Diss. Univ. Utrecht: 221 pp. Zevenboom, D., 1996. Late Oligocene - early Miocene dinoflagellate cysts from the Lemme-Carrosio section (NW Italy); biostratigraphy and palaeoenvironmental interpretation. Giorn. Di Geol. 58(1-2): 80-93.

Ziegler, P.A., 1990. Geological Atlas of western and central Europe. Shell Int. Petr. Mij.: 239 pp.

Ziegler, P.A., 1994. Cenozoic rift system of western and central Europe: an overview. Geol, en Mijnb. 73: 99-127.

Zijerveld, L., Stephenson, R., Cloetingh, S., Duin, E. \& Van den Berg, M.W., 1992. Subsidence analysis and modelling of the Roer Valley Graben. Tectonophysics 208: 159-171. 